\title{
WestVirginiaUniversity
}

THE RESEARCH REPOSITORY @ WVU

Graduate Theses, Dissertations, and Problem Reports

2002

\section{Students' perceptions of nonnative ESL teachers}

\author{
Etelvo Ramos Filho \\ West Virginia University
}

Follow this and additional works at: https://researchrepository.wvu.edu/etd

\section{Recommended Citation}

Filho, Etelvo Ramos, "Students' perceptions of nonnative ESL teachers" (2002). Graduate Theses, Dissertations, and Problem Reports. 717.

https://researchrepository.wvu.edu/etd/717

This Thesis is protected by copyright and/or related rights. It has been brought to you by the The Research Repository @ WVU with permission from the rights-holder(s). You are free to use this Thesis in any way that is permitted by the copyright and related rights legislation that applies to your use. For other uses you must obtain permission from the rights-holder(s) directly, unless additional rights are indicated by a Creative Commons license in the record and/ or on the work itself. This Thesis has been accepted for inclusion in WVU Graduate Theses, Dissertations, and Problem Reports collection by an authorized administrator of The Research Repository @ WVU. For more information, please contact researchrepository@mail.wvu.edu. 
Students' Perceptions of Nonnative ESL Teachers

\author{
Etelvo Ramos Filho
}

Thesis submitted to the

Eberly College of Arts and Sciences at West Virginia University in partial fulfillment of the requirements

for the degree of

Master of Arts

in

Foreign Languages

Frank W. Medley, Jr., Ph. D., Chair Sandra L. Dixon, Ph. D.

Dara G. Shaw, Ed. D.

Department of Foreign Languages

Morgantown, West Virginia

2002

Keywords: Nonnative, Language Teachers, Perceptions

Copyright 2002 Etelvo Ramos Filho 


\section{ABSTRACT \\ Students' Perceptions of Nonnative ESL Teachers}

\section{Etelvo Ramos Filho}

There has been a lot of research on native speaker and nonnative speaker teachers of English as a second language. Authors have addressed negative and positive aspects of these two classes. However, there has not been much research on how students of English as a second language see their nonnative instructors. This qualitative study addresses this issue. In this study I investigated how learners perceive their nonnative speaker teachers. The data were collected through a questionnaire, class observations, and audio-taped interviews with the 16 participants. Two nonnative instructors, who taught the participants, were interviewed also. Overall, despite some negative perceptions, the data indicate that these students perceive their nonnative teachers positively. 
Dedication

To Flavia and my parents, Etelvo and Aryta. 


\section{Acknowledgments}

First of all, I would like to express my gratitude to the members of the committee. Dr. Sandra Dixon, thanks for all the tips and for being so receptive every time I needed help. Dr. Dara Shaw, thanks for having been there since the very beginning. Thanks, also, for being such a wonderful coworker. Dr. Frank Medley, thank you for all your patience, words of encouragement, and promptness in providing me with valuable feedback.

Also, I would like to thank the 16 students and the teachers who kindly agreed to participate in this research. Thanks also to the directors of the intensive English program where the study was carried out.

I want to thank my parents for always supporting me. Thank you, Flavia, for your patience, understanding, words of encouragement, and great computer skills.

I am also immensely grateful to all my professors at West Virginia University, Dr. Ahmed Fakhri, Dr. Frank Medley, Dr. Johan Seynnaeve, the late Dr. Jurgen Schlunk, Dr. Michael Reider, Dr. Susan Braidi, and Dr. Sandra Stjepanovic, for having taught me so much in the two and a half years that I spent at West Virginia University.

Thanks to my former professors and friends at UFES, for their support. Thank you, Joe Pielech, Karla Assis, Luciana Oliveira, and Michael Wilhelm. Thank you, Marina and Eric Spears, for encouraging me to come to Morgantown.

Finally, thanks to all my friends and coworkers who helped me on this project. 
Chapter 1: Introduction ...................................................... 1

Chapter 2: Review of the Literature ........................................... 7

English Language Teaching - Background ............................... 7

Variations of World Englishes ........................................ 15

The Nonnative Speaker Teacher of English ............................... 21

The native speaker: a definition ..................................... 22

Employability .................................................... 23

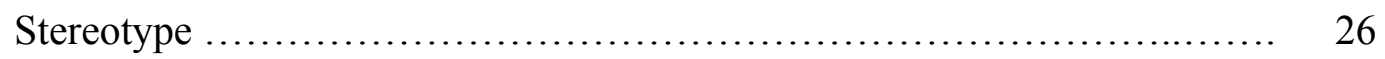

The NNS fallacy and the NNS's competence .......................... 28

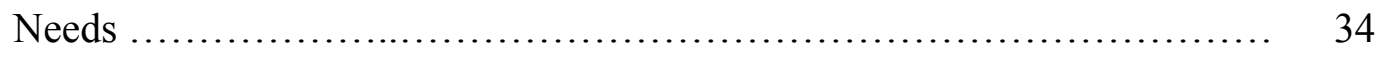

Chapter 3: Design and Methodology ........................................ 40

Research Question.................................................. 40

Qualitative Research............................................... 40

Setting ................................................................ 41

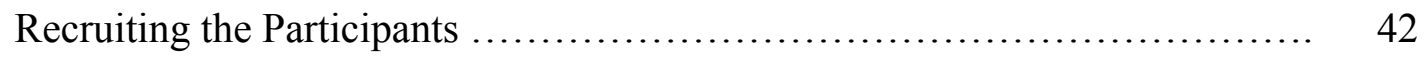

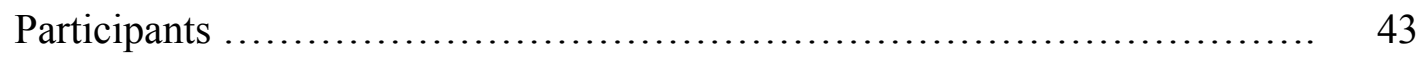

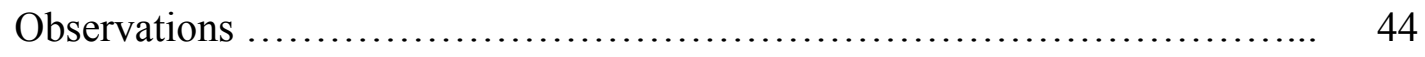

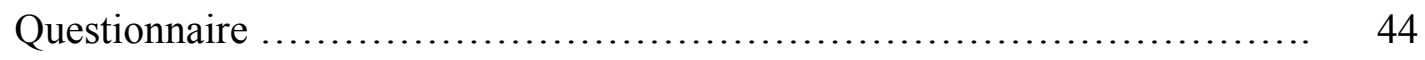

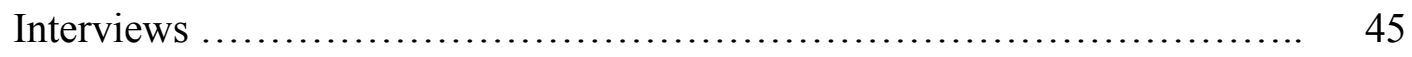

Chapter 4: Findings ...................................................... 46

Students' Perceptions of Nonnative Speaker Teachers' Characteristics ........ 52 
ESL Students' Preferences ......................................... 55

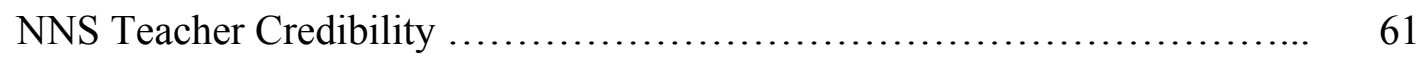

NNS Teachers as Models ............................................ 66

Previous Experiences with NNS Teachers ............................ 69

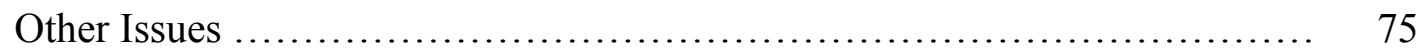

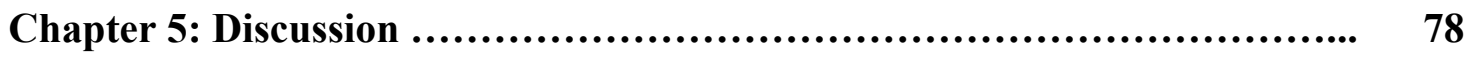

Students' Perceptions of Nonnative Speaker Teachers' Characteristics........ 78

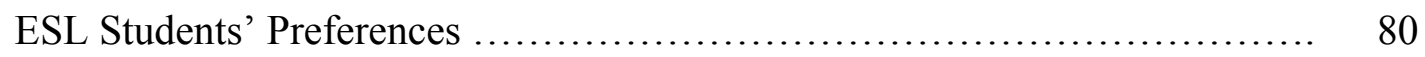

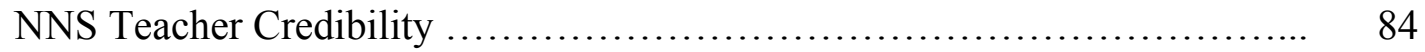

NNS Teachers as Models .......................................... 86

Previous Experiences with NNS Teachers ........................... 87

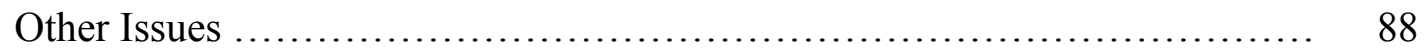

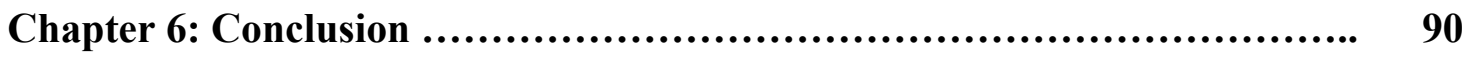

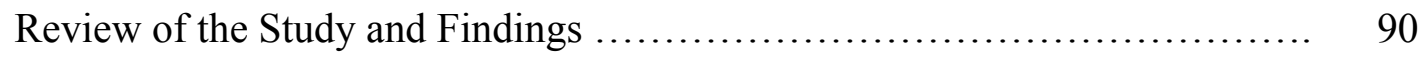

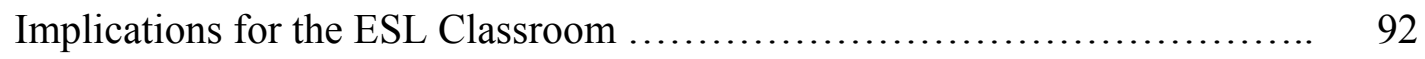

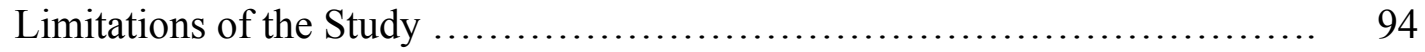

Recommendations for Further Research ............................ 95

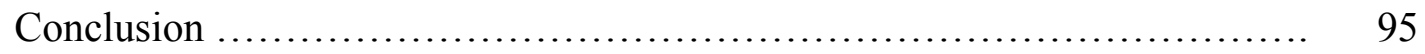

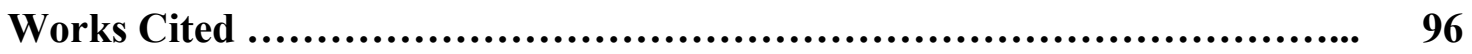

Appendix A $\ldots \ldots \ldots \ldots \ldots \ldots \ldots \ldots \ldots \ldots \ldots \ldots \ldots \ldots \ldots \ldots \ldots \ldots \ldots \ldots \ldots \ldots \ldots \ldots \ldots \ldots \ldots \ldots, \quad 102$

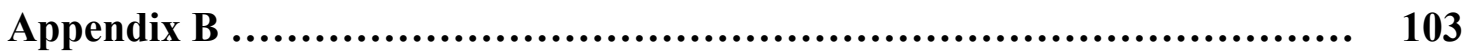

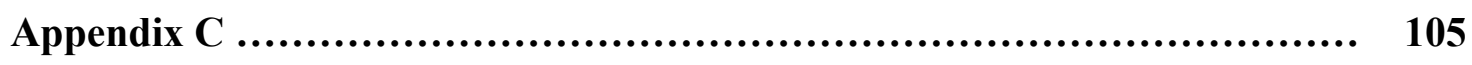

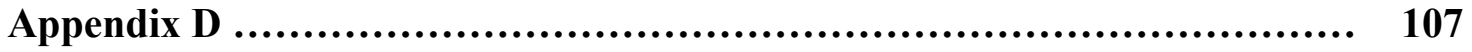




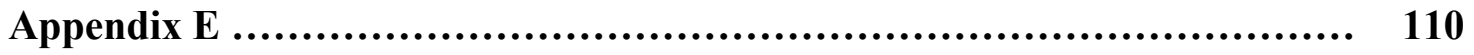

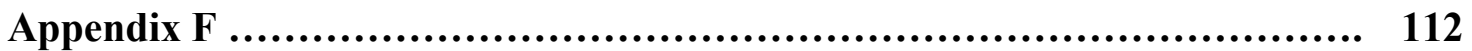




\section{Chapter 1}

Introduction

Much has been written on the native speaker/nonnative speaker (NS/NNS) dichotomy. (Medgyes, 1992, 1994; Phillipson, 1992; Widdowson, 1994; Amin, 1997; Kramsch, 1997; Tang, 1997; Braine, 1999; Brutt-Griffler \& Samimy, 1999; Samimy \& Brutt-Griffler, 1999). Definitions of native as well as nonnative speakers have become abundant in the literature. Kramsch (1997) defines the native speaker as someone who is accepted as such by the group that created the native speaker/nonnative speaker distinction, regardless of birthplace. According to Davies (as cited in Samimy \& BruttGriffler, 1999), from a sociolinguistic point of view, the distinction between native speaker-nonnative speaker is “...one of confidence and identity" (p. 128). The author states that a proper definition of the term NS does not exist. Tang (1997) reports that Medgyes describes native speakers as “...potentially more accomplished users of English than nonnative speakers" (p. 578). Medgyes (1992) speaks of the difficulty in defining who a native speaker is. He asks where a nine-year-old child, having moved to the United States at age five, of foreign parents, would fit - NS or NNS? Widdowson (1994) asks: "who are these native speakers [of English]?" (p. 377). He suggests one answer might be the English. After all, the language originated in England. The Longman Dictionary of Language Teaching \& Applied Linguistics (Richards et al, 1992) defines the native speaker as "a person considered as a speaker of his or her NATIVE LANGUAGE" 
(p. 241). For the purposes of this study, I used Kramsch's definition of the native speaker as a person who is accepted as such by the group that created the native/nonnative distinction, regardless of birthplace.

Beyond definition of the term itself, authors have explored several issues related to NSs and NNSs and the teaching of languages. (Rampton, 1990; Phillipson, 1992; Reves and Medgyes, 1994; Kachru and Nelson, 1996; Amin, 1997; Polio and WilsonDuffy, 1998; Braine, 1999; Liu, 1999; Milambiling, 1999; Samimy and Brutt-Griffler, 1999; Thomas, 1999; Árva and Medgyes, 2000; Shaw, 2001). Some of these issues include credibility, marginalization, competence, stereotype, race, identity, difficulty, strength, and weakness. Unlike their native teacher counterparts, NNSs seem to face more challenges in the ESL classroom by virtue of being identified as a nonnative speaker of English.

Amin's study (1999) shows that having an accent associated with First World nations such as Britain, the United States, and Canada renders speakers a higher status. Similarly, Thuy (as cited in Amin,1999) states that: "The accent with which a foreign born person speaks English can create a favorable or unfavorable impression on a number of Anglo-Americans" (p. 98). According to Thuy, the accent of the NNS is often taken into consideration by many institutions in the hiring process.

The topic of degree of nativeness was explored in a study conducted by Liu (1999). Some of the participants in his study had difficulty in labeling themselves, or accepting the label NNS. Some of his subjects had been studying English since the ages of six, nine, and ten. Accordingly, Kachru and Nelson (1996) advise professionals in the teaching of English to speakers of other languages (TESOL) not to hold too tightly to the 
dichotomy of native speaker versus nonnative speaker. They base this warning largely on their awareness of the diversity of users and uses of English today.

Braine (1999) discusses professional credibility and marginalization of these professionals in the hiring process in North America. Similarly, in Milambiling's survey (1999), one TESOL student said some English as a second language learners may be dissatisfied when having a NNS teacher because they spent a lot of money coming here [United States] for "the real thing" (p. 8).

Furthermore, some language students create a stereotype of what they believe the authentic ESL teacher should look like. Amin (1997) found that some students demonstrated preference for white teachers, assuming only those teachers could be native speakers of English. In a study conducted in the United States, Shaw (2001) had similar findings.

Teaching in an unfamiliar setting is another difficulty some NNSs encounter. In their study, Polio and Wilson-Duffy (1998) noted that international TESOL graduate students are often faced with the challenge of teaching in an unfamiliar context - one in which they were neither brought up nor educated. Chalupa and Lair (2000) report similar findings.

Likewise, Rampton (1990) and Kachru and Nelson (1996) address the NNS label issue. Rampton (1990) suggests that the concept of expertise be used in place of native speakership. Kachru and Nelson (1996) write about problematic issues related to being regarded as nonnative speaker. The authors maintain that attitudinal problems are embedded in the meaning of the nonnative speaker label or English as a second language speaker. They state that "... it is almost unavoidable that anyone would take 'second' as 
less worthy, in the sense, for example, that coming in second in a race is not as good as coming in first" (p. 79).

On the other hand, advantages of being a NNS have been mentioned in the literature. Reves and Medgyes (1994) found that a big strength NNSs have is being able to not only predict their students' difficulties, but also to estimate their potential. The authors add that this sensitivity increases in the EFL context, where NNSs share the linguistic, cultural and educational background with their students. In a study in Hong Kong, McNeil (1994) had a similar finding. The results in McNeil's study show that teachers who share their students' first language (L1) “... are at a distinct advantage when identifying their learners' vocabulary needs" (p. 530).

Moreover, Medgyes (1992) argues that only NNSs can serve as models of what a successful learner should be. He claims that some of the NNSs' strengths are due to their learning of English as a second language. Widdowson (1992) seems to hold a similar opinion when talking about NNSs. "They [NNSs] have been through the process of coming to terms with English as another language" (p. 338). He says that the NNS is the one who has had more experience as an English language learner.

Some authors have dealt indirectly with students' perception of NNS ESL teachers by drawing on the instructors' own perspectives. Liu (1999) reports that some students were not so encouraged by the fact that their NNS teachers had great English proficiency. In fact, they were more intimidated than encouraged. The author claims that because the teachers had mastered the language, the students feared the demands the teachers might have on their students. On the other hand, Polio and Wilson-Duffy (1998) found that novice NNS teachers sensed their students' negative attitudes toward being 
taught by a NNS. Similar attitudes are discussed both in Braine (1999) and by Thomas (1999).

Although much research has been done on NNS teachers, it appears there are few studies investigating how ESL learners see them. Considering this point and Milambiling's suggestion for more research, I carried out a study in an intensive English program (IEP) of a major land-grant institution in the Appalachian region of the United States. In the study, I investigated how ESL students perceive NNS teachers in the program.

Despite the fact that the studies mentioned in the review of literature address both NS and NNS teachers, this study proposes to explore students' perspectives of NNS teachers only. Nevertheless, comparisons may occur if they are necessary to express students' opinions.

A qualitative approach has been chosen for this study. This choice was based on Marshall and Rossman's (1999) view that “Qualitative researchers are intrigued with the complexity of social interactions as expressed in daily life and with the meanings the participants themselves attribute to these interactions" (p. 2). Moreover, as stated by the authors, qualitative research “....relies on people's words and observable behavior as the primary data" (pp. 7-8). Therefore, it is this research stance that most productively can be used to explore students' perceptions of NNS teachers.

Three data gathering sources were used when I conducted the study. These data sources included: first, a student questionnaire which provided a profile of the student participants; second, one-to-one interviews with 16 ESL students and with their two NNS ESL teachers; and finally, 20 hours of class observation because, as stated by Marshall 
and Rossman (1999), class observation may enable the researcher to find "....recurring patterns of behavior and relationships" (p. 107). These three data sources enabled me to triangulate the findings.

This study is organized as follows. In chapter 2, a review of the literature pertaining to the topic is presented. This section comprises a brief history of English language teaching, an account of World Englishes, and a report on studies and opinions by several authors on issues related to NNS teachers of ESL. In chapter 3, I present some background information on the 16 student participants and the two instructors, as well as a description of the design and methodology used in this research study. After collecting the data and assessing the results, I present them in chapter 4 . In chapter 5, I discuss the findings; and finally, in chapter 6 , a conclusion is presented. 


\section{Chapter 2}

Review of the Literature

This chapter consists of three sections. First, a brief background of the literature on English Language Teaching (ELT) shows that the field has always had contributions by and issues about NNSs ever since its early days. Second, a discussion on world Englishes is presented to emphasize the need for ELT instructors to be aware of the variations of English. Finally, issues related to nonnativeness in English Language Teaching are discussed. These issues include the employability of nonnative teachers, stereotypes, the NS fallacy, competence of the NNS, their needs and weaknesses.

\section{English Language Teaching - Background}

Since Howatt's (1984) A history of English language teaching is a comprehensive book on the subject, I rely on it as a major source of information. Howatt (1984) states that the diffusion of English around the world in the wake of trade, building of empire, migration, and colonization has guaranteed a role for the language in the educational history of practically every country in the world. Howatt's account starts in the sixteenth century, when there was no distinction between English as a mother tongue and English as a foreign language. For example, the author relates that the proposals of the phoneticians, grammarians, and spelling reformers addressed both the native speaker and the foreign learner. Only in the twentieth century, he adds, do we see the beginning of “...a separate identity for English as a foreign language" (p. xiii). Also, the author places the teaching of English embedded in the language teaching context as a whole.

In the sixteenth century, there was an interest in putting English on the same level of, or in surpassing the prestigious Romance languages of Europe. French was used by 
many learners as a means to learn English philosophy and literature. Nevertheless, some people found this dissatisfying. They preferred to read English works in English. Thus, the interest in learning English increased. However, a standardization of the language needed to be established. This being done, foreigners would be impressed and would be more interested in English literature. This project of standardization of English included fixing its orthography, and writing a grammar of the language. Sir Thomas Smith, William Bullokar, Richard Mulcaster, John Hart, Alexander Gill, Charles Butler, John Wallis, and Christopher Cooper were some of the contributors committed to this enterprise between 1550 and 1700. In addition, Howatt also mentions great dictionarymakers like Samuel Johnson, John Walker, and Noah Webster; all of whom contributed immensely to the standardization of English.

Triggered by a great interest in the dramatic works of English literature, particularly those by Shakespeare, many publications for language learning became available. The real breakthrough in publishing, however, happened in Germany. Some of these textbooks were: Double-grammar for Germans to learn English and for Englishmen to learn the German tongue (1687); Grammatica Anglicana Concentrada, oder kurz-gefasste englische Grammatica [Summary of English Grammar] (1736); and, with a focus on English phonology and prosody, Englische Sprachlehre für die Deutschen [English Course for Germans] (1792). In addition, there were other grammar textbooks, written by teachers of Italian, whose focus was on translation and dialogues for traveling.

In the late sixteenth and early seventeenth centuries, there were two schools of thought in language studies education. The first school focused on "...language and the 
nurture of an elegant and flexible style for courtly use" (Howatt, 1984, p. 33). This school was established by Erasmus and Vives, and reiterated by Roger Ascham. It was the representation of the humanist tradition. The second school, which was launched by Francis Bacon, and had its peak with the work of Jan Amos Comenius, had a more puritanical philosophy. Bacon (1605), in his The advancement of learning, criticized the “...overly fussy concern for style at the expense of content" (p. 34). Comenius wanted to lead his students toward the exploration of nature, of men belonging to a great world, rather than remain in the isolation of their own little worlds. Language would thus serve as the means by which this exploration would take place.

In the second half of the seventeenth century, 1685, the Swiss Guy Miège published Nouvelle Méthode pour apprendere l'Anglois [New Method for Learning English], which is considered a landmark in ELT. As Howatt states, Miège's book: “...raised the teaching of English as a foreign language to a standard of expertise and professionalism it had not enjoyed before" (p. 53). His methods were based upon teaching pronunciation, spelling, grammar, and the use of dialogues and phrases to practice the language. In addition, Miège's work complemented contemporaneous works of native grammarians by focusing on grammatical topics such as the progressive aspect and the past continuous.

Howatt notes that Miège was a courageous grammarian. Despite being a nonnative speaker of English, Miège translated his Nouvelle Méthode into English; which he called The English Grammar. Nevertheless, his works in the development of English grammar were overshadowed by the works of John Wallis (1653) and Christopher 
Cooper (1687). Howatt adds that Miège's lack of success with The English Grammar may have been due to the fact that he was a nonnative grammarian.

In eighteenth-century Britain, the teaching of English as a foreign language was intense due to the immigration of newcomers who were moved by religious and political disturbances. Abroad, the interest in English philosophy and literature continued to grow. However, the language was now being taught from textbooks written by nonnative speakers. It was in the eighteenth century that the spread of ELT found its way in Europe. First, it arrived in France, then in the Netherlands, Denmark, and Germany, while countries of the Mediterranean and Baltic came next. Russia was the last one at the end of the century. It is worth mentioning that the only European countries with a history of English language teaching at that time were France and the Netherlands. In these countries, it started before 1600 . The author adds that, in 1662, James Howell wrote the book A new English grammar, prescribing as certain rules as the language will bear, for foreigners to learn English for Portuguese and Spanish speakers.

The eighteenth century saw some new approaches to language teaching described. The two most successful ones were: Elements of the English language, explained in a new, easy, and concise manner, by way of dialogue, by V. Peyton (1761), and Élémens de la langue angloise, ou méthode pratique pour apprendre facilement cette langue [Elements of the English Language, or Practical Method for Learning this Language Easily], by L. P. Siret (1773). Besides being published in Europe, both of these courses were also published in Philadelphia in 1792. Moreover, the first non-European textbook for the teaching of English appeared in Bengal in 1797. 
In his survey of language teaching in the eighteenth century the author also mentions The tutor, a book produced in a Third World country. It was published in India in 1797. Some of the features that The tutor presents are the English alphabet, lists of vocabulary, lists of phonetically contrastive sets, and grammar. The latter is presented incidentally in practical river-boat-related dialogues.

According to Howatt, “...the grammars, dictionaries, and other manuals of language in the seventeenth and eighteenth centuries took the form they did, and exhibited the priorities they did, because they were addressed to an audience that had practical need of them" (p. 78). Compared to the modern notion of language teaching, he adds, the influence of Latin, neglect of speech, and emphasis on correct grammar, may be seen as faults. However, they fulfilled the needs of the learners for whom they were intended.

Just as textbooks were being produced and published, so, too, were lexicographers at work. Some of the great contributors to the making of dictionaries were S. Johnson (1755) with his $A$ dictionary of the English language, J. Walker (1791) with A critical pronouncing dictionary, and N. Webster with A compendious dictionary of the English language and An American dictionary of the English language, published in 1806 and 1828, respectively. Walker's dictionary contained a brief note entitled 'Directions to Foreigners", which focused on the problems of French-speaking learners. With the advent of America's move toward cultural independence from London, Webster saw the need for a reformed system of spelling of American English. His The American spelling book, published in 1787 , became very popular. 
Up to 1800 , Howatt mentions four groups of learners for whom the grammars and dictionaries of English were written: "foreign students of the language, school pupils, private scholars, and a growing number of socially and professionally ambitious 'middle brow' learners" (p. 78). These foreign students were mostly academics and scholars whose focus was on acquiring a reading knowledge of English.

Howatt talks about the two paths that ELT took after the close of the eighteenth century. The first path is related to the role that English was to play in the educational context in the imperial expansion, and the second is related to language teaching, social, and educational changes in Europe in the nineteenth century.

In the nineteenth century, foreign language teaching became gradually integrated into modernized secondary school curricula. The focus on accuracy, and the neglect of spoken language that was characteristic of the Grammar-Translation Method suited the attitude in language teaching at the time. The Grammar-Translation Method (GTM) began in Germany at the end of the eighteenth century. Johann Christian Fick (1793) wrote the first Grammar-Translation Method course for the teaching of English. It was published in Erlangen, South Germany. According to Howatt (1984), the GTM had as main feature "...the replacement of the traditional texts by exemplificatory sentences" (p. 131), and as main goal the making of “...language learning easier” (p.131). However, as a drawback, Howatt mentions that it was not suitable for younger school students. Also, he adds that it was inappropriate for classroom teaching because it was a self-study method.

Toward the end of the nineteenth century, many leading phoneticians and teachers worked together having in mind “... a shared educational aim...” (p. 169). As a result, 
many works related to language teaching, including those of Viëtor (1882), Franke (1884), Klinghardt (1888), and Sweet (1899) were published. In addition, Howatt mentions the formation of professional associations and societies - namely the International Phonetic Association and its International Phonetic Alphabet (IPA).

This cooperation of teachers and phoneticians is known in the field of historical linguistics as the Reform Movement, which had the purpose of bringing about educational change. Its basic principles were “...the primacy of speech, the centrality of the connected text as the kernel of the teaching-learning process, and the absolute priority of an oral methodology in the classroom"(p. 171). Two of the problems in ELT that the proponents of the Reform Movement proposed to tackle were the workload on students, and the lack of emphasis on speech in the classroom. Howatt expresses Viëtor's dissatisfaction about the lack of speech by saying that, "if speech was taught at all, it was badly done by teachers whose own pronunciation was inadequate" (p. 172). For this reason, Viëtor (1882) wrote Der Sprachunterricht [Language Teaching], whose focus was on "...the primacy of the spoken language" (p. 172). The Reform Movement had its peak with The practical study of languages, by Sweet (1899), and How to teach a foreign language, by Jespersen (1904).

According to Richards and Rodgers (1986), an interest in teaching language in a naturalistic manner was arising concurrently with the Reform Movement. The naturalistic principles for language teaching were based on those of first language acquisition. As stated in Richards and Rodgers (1986), a more natural approach to language teaching was finding many followers: "Sauveur and other believers in the Natural Method argued that a foreign language could be taught without translation or the use of the learner's native 
tongue..." (p. 9). In addition, other authors were putting forth the principles of the Natural Method. Richards and Rodgers (1986), quoting Franke (1884), stated that “...a language could best be taught by using it actively in the classroom" (p. 9). The authors add that instead of focusing on grammar analyses, "teachers must encourage direct and spontaneous use of the foreign language in the classroom" (p. 9). These naturalistic principles of language teaching served as a basis for the Direct Method, which was widely used in the United States by Saveur and Berlitz, although Richards and Rogers add that Maximilian Berlitz never made use of the name Direct Method. Rather, he used it in his schools as the Berlitz Method.

Richards and Rodgers (1986) state that the Direct Method worked quite successfully in private schools. However, it had some drawbacks. It did not work as successfully in public schools because it did not envisage the practical realities of the classroom (Richards \& Rodgers, 1986). In addition, according to Richards and Rodgers, it depended on NS teachers, or teachers whose fluency was native-like. Moreover, as the authors state, "Critics pointed out that strict adherence to Direct Method principles was often counterproductive..." (p. 10). For example, so as to avoid using the native tongue, teachers would spend much time attempting an explanation. In many cases, using the mother tongue would have been more efficient.

Even though the Direct Method became popular in Europe and in the United States, by the 1920s it began declining. In the United States, language teaching shifted toward reading and grammar. In Europe, the British linguist Henry Sweet argued that the Direct Method had its limitations because it lacked a thorough methodological basis, in spite of offering some innovations in teaching procedure 
(Richards \& Rodgers, 1986, p. 11). As a result, applied linguists of the 1920s and 1930s organized the principles set forth by the Reform Movement, which laid the foundations for subsequent approaches to the teaching of English as a foreign language.

Regardless of the methods proposed, it was implicit that the teachers would have native or native-like control of the language. The following section reviews the literature on the variations of English in the world, and how they are related to the dichotomy between native speaker teachers and nonnative speaker teachers.

\section{Variations of World Englishes}

English can have many variations within a single country where it is spoken. Rickford's (1996) discussion includes the effects that geographical region, social class, age, and ethnic background play on the linguistic features of a speaker of the language. One country that the author used to exemplify these variations was the United States. Thus, he discusses African-American Vernacular English, New England English, Southern English, and so on. According to the author, "understanding and recognizing such variation is essential for language arts and second and foreign language teachers" (p. 15). As we shall see later, the way one speaks English may be a factor in how students perceive their teachers, both in terms of their "nativeness" and in terms of the acceptance of the teacher as a linguistic model.

In their article entitled World Englishes, Kachru and Nelson (1996) state that English is undoubtedly "the most widely taught, read, and spoken language that the world has ever known" (p. 71). According to Kachru (1982), John Adams foresaw this in the eighteenth century maintaining that, "English will be the most respectable language in the 
world and the most universally read and spoken in the next century, if not before the close of this one" (p. 2).

Kachru and Nelson (1996) envision the spread of English worldwide as "two diasporas" (p. 72). The first is related to the migrations of large numbers of English speakers from the British Isles to places such as Australia, New Zealand, and North America. The users of the language brought with them their language, which changed over time. The authors explain that the second diaspora of English took place in the colonial contexts of Asia and Africa. However, they add, this diaspora "entailed transportation of the language, but only to a small extent transportation of Englishspeaking people" (p. 72). In spite of the very small number of native users of the language, it became of great importance and usefulness in these new sociocultural contexts, where much larger local populations "have continued to expand the roles of English" (p. 72). The authors add that it is worth noting that, as English connected with the cultures and languages of Asia and Africa, the linguistic changes were widely divergent. Moreover, their cultures "were far removed from the experience and common presuppositions of the native English speakers" (p. 72). According to Kachru and Nelson (1996), these varieties of contemporary Englishes share many characteristics. Nevertheless, they are unique when it comes to grammar-related innovations and tolerances, lexical items, pronunciations, idiomatic expressions, and discourse. Also, they add, these striking variations in English have emerged as a result of these language contacts.

In their discussion of varieties of English that are commonly accepted today, the authors include American, British, Australian, Canadian, and New Zealander. In addition, 
they provide a list of countries in which English is the official language. (Appendix A). They add that there may be cases in which English is a co-official language. Also, usage may make it official. As Kachru and Nelson (1996) point out: “...or it may be, as in the United States, the official language in fact though not in law" (p. 74). According to the authors, some features of the language determine which variety of English is being used. Also, the accent or pronunciation of the speaker can demonstrate which variety of English he/she uses. In texts, however, the variety is depicted in the writer's choice of lexis, collocations, and grammar. To illustrate this, the authors mention that if one glances at the front pages of the New York Times, the London Times, the Times of India, and Singapore's The Straits Times, more similarities than differences will be noticed. However, depending on the reader's background, he/she may come across unfamiliar features.

In view of this, the authors argue that “...it is imperative that teachers and students be aware of the sort of presence that English has in the world today..." (1996, p. 76). Also, if there are differences, it does not mean that one form is correct and the other is not. They argue that the concept of monolithic English is no longer easy to maintain. What we have today is English languages and English literatures. And, it is essential to be aware of their spread, uses, users, and sociolinguistic contexts. Likewise, Strevens (1977) says that the fact that ELT teachers today are aware that English is not a “...single, homogeneous language" (p. 119) is relevant to the teaching of English as a foreign or second language. He holds that the increase in diversity generates anxieties related to acceptability “... especially for non-native speakers of the language, and, above 
all, for those concerned with language education" (1980, p. 61). Moreover, Strevens

(1992) suggests that an international standard is maintained in spite of the varieties: There exists an unspoken mechanism, operated through the global industry of ELT teaching, which has the effect of preserving the unity of English in spite of its great diversity. For throughout the world, regardless of whether the norm is native-speaker or non-native speaker variety, irrespective of whether English is a foreign or second language, two components of English are taught and learned without variation: these are its grammar and its core vocabulary ... the grammar and vocabulary of English are taught and learned virtually without variation throughout the world (Strevens, 1992, as cited in Graddol, 2001, pp. 27-28).

Rampton, in his 1990 article, also mentions that considerable effort is being made to bring to light the legitimacy of Englishes worldwide, although they may be regarded as “...the other tongue or nativized varieties..." (p. 97).

In their section on types of variations and types of users, Kachru and Nelson (1996) talk about three concentric circles where English is used: the Inner Circle, the Outer Circle, and the Expanding Circle. The Inner Circle encompasses “...the old-variety English-using countries...” (p. 77): the United States, Britain, Canada, Australia, and New Zealand. The Outer Circle refers to countries such as India, Nigeria, Pakistan, Singapore, South Africa, and Zambia. They are “...countries where English has a long history of institutionalized functions and standing...” (p. 78). That is, the role of English in education, government, literature, and popular culture is very important in the Outer Circle countries. Finally, the Expanding Circle comprises countries where English is 
widely studied. Nevertheless, its use in education is more specific. It is used for scientific and technical reading, for instance. Currently, some of the countries that form the expanding circle are China, Indonesia, Iran, Japan, Korea, and Nepal.

Authors (e.g. Graddol, 2001; Kachru \& Nelson, 1996, Pennycook, 2001) have written about the large number of English users worldwide. Kachru and Nelson (1996) argue that this number is " ....almost unimaginable to the monolingual, monocultural English teacher" (p. 78). Kachru and Nelson (1996) believe there are at least three nonnative users to every native user. Moreover, they add that it is difficult to define a user of English in relation to either amount of use or level of proficiency. In addition, they argue that "being labeled a native speaker is of no particular a priori significance, in terms of measuring facility with the language" (pp. 78-79). As an illustration of this point, Kachru and Nelson (1996) mention the complaints of professors in universities in the United States. The professors complain about their freshman composition students' lack of sense of idiom, poor writing, and limited vocabulary.

Kachru and Nelson (1996) reiterate that it is essentially important that English language teaching professionals recognize the vast variety of users and uses of English today. The authors say that the new cultures in which English is being or has already been adopted as a lingua franca have their own features of discourse. They hold that the study of their discourse pragmatics is necessary so that speech act features such as politeness, apology, persuasion, and so on are understood. Based on studies of the above linguistic features, it would be "...relatively easy to design hands-on experience tasks for students and teacher trainees" (p. 97). Similarly, Crystal (2001) says that learners need to be exposed to the many varieties available today; especially those they are likely to 
encounter in their regions. In view of this, Crystal (2001) states that "...teachers need to prepare their students for a world of staggering linguistic diversity" (p. 60). Moreover, he continues saying that:

teachers need to develop a truly flexible attitude towards principles of usage. The absolutist concept of ‘proper English' or 'correct English', which is so widespread, needs to be replaced by relativistic models in which literary and educated norms are seen to maintain their place alongside other norms, some of which depart radically from what was once recognized as 'correct' (p. 60).

Graddol (2001) argues that one question arises in any discussion of global English: "Will a single world standard for English develop?" (p. 26). It appears that there is no simple answer to the question. As the author puts it, this question has at least two dimensions:

the first is whether English will fragment into many mutually unintelligible local forms; the second is whether the current "national" standards of English (particularly US and British) will continue to compete as models of correctness for world usage, or whether some new world standard will arise which supersedes national models for the purposes of international communication and teaching (pp. 26-27).

To conclude this section on World Englishes, I decided to resort to Edge's (1988) and Strevens'(1980) discussion about choosing which English to teach; given the immense variety available. Edge (1988) argues that in a country where "...there is no established local variety of the language, a standard model should be used in order to 
increase the likelihood of international intelligibility" (p. 155). Likewise, Strevens states that "different models of English are likely to be suitable in EFL areas, as contrasted with ESL areas" (1980, p. 90). Moreover, he adds that, for the most part, in English as a Foreign Language (EFL) contexts, the “...most suitable pedagogical model is usually a native-speaker model (British, American, Australian, New Zealand, etc.)” (Strevens, 1980, p. 90). Conversely, for ESL areas where local L2 forms of English have developed and have been approved by the population, the author makes another suggestion. He argues that in such areas these localized forms are "...the most suitable for models for use in schools, certainly more suitable than a British or American L1 model” (1980, p. 90). He concludes by saying that English belongs to the world, "... and new forms of English, born of new countries with new communicative needs, should be accepted into the marvellously flexible and adaptable galaxy of 'Englishes' which constitute the English language" (p. 90).

\section{The Nonnative Speaker Teacher of English}

In recent years, many authors (Strevens, 1980; Kachru and Nelson, 1996; Graddol, 2001) have talked about the constantly increasing number of varieties and users of English worldwide. Also, authors have discussed the ownership of English in the world of TESOL (e.g. Norton, 1997; Widdowson, 1994). Concurrently, there has been a great deal of discussion on the topic of native speaker and nonnative speaker teachers of ESL. Researchers have written on positive as well as negative aspects of being a native/nonnative ESL teacher. Among some of the issues commonly discussed are: credibility, marginalization, stereotype, competence, strengths, needs, and weaknesses. In this section, I deal with these issues. Moreover, I draw on studies and opinions by various 
researchers to present some of the issues surrounding the nonnative speaker teacher of ESL.

The native speaker: a definition.

One big issue related to this topic is arriving at a consensus on the definition of a native speaker. Paikeday (1985), who has been interested in the topic since the 60s, states that a lay person would say that a native speaker "...may mean someone who speaks a native language, like an Iroquois or Athabaskan!” (p. 95). Moreover, Paikeday (1985) states that the “...term 'native speaker' has perplexed this dictionary editor [himself] for well nigh 25 years" (p. 95). Edge (1988) says: “One relatively uncontroversial definition might be based on the accident of birth and growing up; that is to say that a person is a native speaker of a language that he or she learnt first as a mother tongue" (p. 154). Nevertheless, the author points out that this statement is controversial for the fact that many people are born and grow up in multilingual societies. Davies (1991), as cited in Samimy and Brutt-Griffler (1999), says that the distinction between native speakernonnative speaker is “... one of confidence and identity” (p. 128). He says that a proper definition of the term native speaker does not exist. Medgyes (1992) speaks of the difficulty in defining a native speaker. Within the context of ESL and EFL, he states that NSs are "...potentially more accomplished users of English than nonnative speakers" (p. 578). Given the diverse definitions of a native speaker, for the purpose of this study, I draw on Kramsch's assertion. Kramsch says: "Native speakership, I suspect, is more than a privilege of birth or even of education. It is acceptance by the group that created the distinction between native and nonnative speakers" (1997, p. 363). Having discussed the 
native speaker, I now turn to a discussion of the nonnative speaker and some of the issues this label entails.

\section{Employability.}

Forhan (1992) states that TESOL is against the discriminatory actions against NNSs in hiring practices. The author says: “A TESOL statement on Nonnative Speakers of English and Hiring Practices (Appendix B) offers recognition and support to the thousands of well-qualified professionals throughout the world who are teachers of English to speakers of other languages" (p. 23). Rampton (1990) claims that if one is judged by what he/she knows and, implicitly, is able to do with the language, as opposed to where he/she comes from, recruitment of teachers will be a fairer process. Leung, Harris and Rampton (1997) question the pedagogical importance of the notion of native speakership. Instead, the authors propose that TESOL professionals “... be concerned with questions about language expertise, language inheritance, and language affiliation" (p. 543). However, the barriers that NNS teachers of English face suggest that the TESOL position is not embraced unanimously.

Numerous studies have established that there is clear and obvious discrimination against NNS teachers of ESL in the job market (Braine, Thomas, Amin, Kamhi-Stein, Waleign, Illés, Lee, Shaw). They have voiced their opinions based on personal experience and research on the topic. Braine (1999) makes an analogy that illustrates the problems of academic and professional credibility NNS professionals encounter in the hiring process in North America. He says: “...unlike medical graduates, non-native educators are not considered vital or lifesaving; instead, they are often regarded as unnecessary by-products of the MA and Ph.D. programs in applied linguistics and 
TESOL in North America" (p. xiii). In spite of their training, he states, nonnative speakers who are educators are denied employment in the field of ESL. According to Braine, upon arriving in North America, many of these professionals have their credentials questioned and their accents misunderstood. Hence, they end up being marginalized in the profession. The author states that some intensive English program administrators do not hire nonnative teachers: “...some administrators have openly stated so at professional conferences and job interviews..." (p. xvi).

Likewise, Thomas (1999) reports on a discriminatory comment heard at the 1995 TESOL convention. In a session on recruitment, a participant said: "One thing that we do when we recruit, is that we tell students that they will only be taught by NSs. After all, these students don't come so far to be taught by someone who doesn't speak English" (pp. 6-7). Thomas argues that such a statement implies that if someone is not an NS of English, he/she cannot speak the language. The author states that in order to establish their credibility as teachers, NNSs have to do twice as well.

Amin (2001) argues that minority immigrant teachers are regarded by their colleagues and students as “...not knowing standard English and not having a standard accent” (p. 9). Thus, they are seen as less qualified than their Canadian counterparts. Moreover, she claims that this is the result of “...the native speaker norm of ESL programs..." (p. 9). According to Amin (2001), this norm in ESL programs in Canada gives "...students the message that their immigrant teachers cannot provide them with Canadian English that they need in order to assimilate and become successful...” (p. 9). Similar recruiting policy is observed outside North America. Kamhi-Stein (2000) reports anecdotal evidence suggesting that a similar situation exists in some Latin 
American countries, where non-qualified NSs are hired in place of professional NNSs. The author states that native speakers of English are often considered for teaching jobs “...regardless of whether or not they have had TESOL training" (p. 11). As a result, although the NNSs have had formal training and experience in TESOL, they are still at a disadvantage in the hiring process.

Likewise, Walelign (1986) argues that nonnative speaker teachers are sometimes judged solely on their accents, regardless of their professional preparation. He states that "Often the demands made on the nonnative applicant have little bearing on what is actually required to handle a teaching job properly" (p. 40). Moreover, the author observes an "....inordinate amount of emphasis placed on the right accent, and the tendency to look unfavorably on a nonnative speaker's suitability purely on the basis of how his or her 'accent' is perceived to deviate from the 'standard"' (p. 40). Walelign maintains that the difficulty that nonnative professionals encounter in the job market is the result of a popular misconception. The idea "...that a nonnative speaker is necessarily incapable of teaching the language - irrespective of the nature of his or her association with the language, and regardless of the level at which it is to be taught" (p. 40) is supported by major recruiting organizations. The author supports his claim by mentioning advertisements such as: "Applicants should be native speakers of English, [British] citizens, and with [a British] educational background" (p. 40).

Another similar example shows the difficulty that NNSs are faced with in the hiring process in the United Kingdom. Illés (1991) quotes a paragraph in one of the many letters of rejection received by a qualified NNS applicant to ESL positions. One of the many refusals the applicant received featured the following paragraph: "I am afraid we 
have to insist that our teachers are native speakers of English. Our students do not travel half-way round the world only to be taught by a non-native speaker (however good that person's English may be)” (p. 87). As Illés (1991) points out, this “...view carries the unmistakable implication that native English speakers are blessed with the innate capacity to teach" (p. 87).

Stereotype.

Among other sources, the issue of stereotype is discussed in Amin (1997), Lee (2000), Shaw (2001), and Thomas (1999). Amin (1997) states that some ESL students believe there is an intrinsic connection between race and language. She bases her statement on a study she conducted in Canada in 1994, her own experience, and that of other teachers. The researcher had as participants five non-white female teachers who were teaching or had taught a class of adult ESL students from different racial, cultural, and linguistic backgrounds. She conducted a two-hour semi-structured interview with each teacher. The 25 questions that she asked were related to what teachers think their students' ideal ESL teacher is. She found that “...the teachers believed that some ESL students make the following assumptions: (a) Only White people can be native speakers of English; (b) only native speakers know 'real' English; and (c) only White people are 'real' Canadians"' (p. 580). Amin, an ethnic Pakistani herself who emigrated to Canada as an adult, concurs with the perceptions of the teachers who participated in her study. Moreover, the author states that she often has her knowledge of English put to check. She says, "I am constantly being challenged on the rules of English grammar, and it seems to me that some of my students are waiting for me to make a mistake" (p. 580). Amin concluded that non-white teachers are seen as less capable professionals. 
Shaw (2001) had similar findings. In a study carried out in an intensive English program at an American university, she found that some ESL learners “.... were critical of the teachers who did not 'look like' U.S. Americans”' (p. 231). According to Shaw (2001), some ESL students assume that teachers who do not look like U.S. Americans “...will not be able to effectively teach English" (p. 231). The author adds that often ESL students are unaware of the great "...cultural and racial diversity that is pervasive in the United States...” (p. 231). The ESL students' lack of understanding, suggests Shaw, may contribute to their linguistic biases against nonnative ESL teachers. According to Shaw (2001), it did not occur to these learners that the teachers who did not look like Americans might have lived in the United States all their lives. The researcher maintains that some direct comments made by the students "... seem to reflect a possible bias in favor of teachers who 'looked' liked U.S. Americans or Northern Europeans" (p. 85).

Likewise, Lee (2000), a Hong Kong native immigrant to British Columbia, says that being a minority teacher is very challenging. She is aware that "...it requires much more effort to convince students that NNS teachers can be equally good, if not better, English teachers than their native speaker (NS) counterparts can" (p. 19). As the only Asian in her ESL department, Lee feels discriminated against by her students. She has been asked questions such as: “'Are you a volunteer?' and 'What are your qualifications?'” (p. 19). Similarly, Thomas (1999), an Indian-born professional, reports on one of her ESL student's comment upon seeing her for the first time: "You know 
when I saw you enter the class on the first day, I was disappointed. I had spent a lot of money to come to the United States and I was hoping to get a NS to teach the class" (p. 8).

It is important to emphasize that the anecdotes and the empirical research about NNS instructors described here do not intend to single out one group, NSs or NNSs, as the best teacher. The issue is not one of nativeness, nor of who is better. It is a question of qualifications to be in the classroom, and the effectivenes of the teacher without regard for NS-NNS status.

The NS fallacy and the NNS's competence.

According to Canagarajah (1999), the notion that the ideal teacher of English is a native speaker of that language (referred to in the literature as "the native speaker fallacy") discredits the NNS's competence. Opposing the findings in the literature, the author argues that “...speakers with multilingual competence, even in a situation where the language is a foreign or second language, may make successful language teachers" (p. 80). Moreover, the proficiency they have in more than one language helps them develop “...deep metalinguistic knowledge and complex language awareness” (p. 80). Whereas native speakers are believed by many students to be endowed with the inborn capacity to teach, that does not seem to be the case with their nonnative counterparts. Many authors (e.g. Canagarajah, 1999; Coppieters, 1987; Cook, 1999; Rampton, (1990); Thomas, 1999; Walelign, 1986; Widdowson, 1994) have written about cases when NNSs have their linguistic competence put to check. Walelign (1986) states that the term native speaker misleadingly implies that “... a person is thoroughly proficient in [his/her language]..." (p. 40), and notes that this is not always the case, for 
there are native speakers whose command of the language is not quite adequate. On the other hand, there are NNSs who, "... due to the nature and duration of their exposure to the target language, are completely proficient" (p. 40). Rampton (1990) holds a similar opinion. As the author points out, “...Being born into a group does not mean that you automatically speak its language well - many native speakers of English can't write or tell stories, while many non-native speakers can" (p. 98). Moreover, he says, no one has total functional command of a language - users have better proficiency in some areas than in others. On the lack of credibility encountered by NNSs, Widdowson (1994) maintains that, undoubtedly "...native speakers are deferred to in our profession" (p. 386). The author argues that NS teachers have been privileged by this notion of authenticity. According to Widdowson (1994), there has been great emphasis on the use of authentic materials and natural language in the classroom in recent years. As a result of this “....authenticity primacy as a pedagogic principle, you inevitably grant privileged status to native-speaker teachers, and you defer to them not only in respect to competence in the language but also in respect to competence in language teaching” (p. 387).

Milambiling (1999) states that “...the label 'non-native' implies a deficit when in fact this is not the case at all" (p. 4). Moreover, she claims that her experience as a professional in a TESOL training program at a midwestern university has enabled her to see that the resourcefulness of nonnative speakers in TESOL have been “...underestimated and underutilized..." (p. 4). The author argues that many of the nonnative speaker trainees “...will actually be more successful at teaching English than would native speakers in the same teaching situations" (p. 4). Milambiling says that among the reasons for this is that the NNS trainees may share their learners' "thought 
worlds" because of their experience as language learners themselves. Similarly, Cook (1999) maintains that NNSs “....are successful multicompetent speakers, not failed native speakers" (p. 204).

In spite of the fact that she tells people she is a native speaker of Indian/Singapore English, Thomas (1999) has been frequently complimented on her good English in the United States. She states that this sort of attitude stems from the "...fallacy that there is only one kind of English, the right kind - the kind spoken by people belonging to the 'inner-circle"” (p. 7). The author argues that the fallacy “...undermines the competence of both NSs and those who have 'near native proficiency' in international varieties of English" (p. 7).

In attempting to ascertain the competence level of NNSs, several studies have been conducted (Coppieters, 1987; White \& Genesee, 1996; Palfreyman, 1993). In a study on differences in competence between native and near-native speakers of French, Coppieters (1987) found that it appears that the two groups have developed “...significantly different grammars for French" (p. 565). The participants in his study were two groups: 21 NNSs of different linguistic background who had acquired French as adults; and 20 NSs. In order to investigate the possible differences between the linguistic competence of the two groups, a list containing 107 sentences featuring various aspects of French was used. The participants were interviewed and the researcher discussed with them their interpretations of the sentences. Coppieters (1987) found that the two groups' interpretations of the sentences were significantly divergent. The author states that "...this is so in spite of the fact that the two groups appear to be equivalent at the level of language use and proficiency" (p. 544). 
Birdsong (1992) pointed out problems with the task and selection of participants used by Coppieters. He then modified the methodological procedures employed by Coppieters and tried to replicate the difference in competence that the researcher had found. According to Birdsong, Coppieters had a very heterogeneous group of participants: “...2 subjects representing Farsi, only 5 subjects representing 'Oriental' languages, and 6 different native languages among the 14 native speakers of Germanic and Romance [languages]" (Birdsong, 1992, p. 716). On the other hand, Birdsong (1992) had a homogeneous group of NNSs. The participants in his study were 20 NSs of English who had been exposed to French after puberty and were near-native speakers of French, and 20 NSs of French. Birdong (1992) administered three tasks:

The first task involved judgments for the most probable interpretation of decontextualized ambiguous sentences. The second task required subjects to examine decontextualized sentences containing the adverb bien, and to decide which of several possible meanings for bien was the most appropriate. The third task required subjects to judge the acceptability of French sentences chosen to exemplify + UG and - UG constructions (Birdsong, 1992, p. 716).

Birdsong found a much lower incidence of divergence between the NSs and the NNSs than Coppieters had found. Birdsong (1992) concluded: "Although it is encouraging that the results of the three tasks converged on the conclusion that nonnatives can attain native-like norms, the evidence is far from decisive" (pp. 741-742).

White and Genesee (1996) also carried out a study in order to ascertain the achievement of native-like performance by nonnative speakers. The subjects were 89 speakers of English as a second language and 19 monolingual native speakers of English. 
They were classified into three groups: near-native speakers of English, nonnative speakers and controls. The sixty sentences used in the test had been piloted on native speakers, who gave their judgment on grammaticality. White and Genesee (1996) state that: "Overall, the response patterns of the native speakers and the near-natives are almost identical..." (p. 258). The results of the study suggest that “...ultimate attainment in a second language (L2) can indeed be native-like in the UG [Universal Grammar] domain" (p. 258). Moreover, they argue that their findings “... suggest that native-like attainment is possible regardless of age of initial significant exposure to the L2" (p. 258).

Medgyes (1992) argues that NNSs “...can never achieve a native speaker’s competence. The two groups remain clearly distinguishable" (p. 342). According to the author, nothing can change this: “...whether it be motivation, aptitude, perseverance, experience, education, or anything else" (p. 342). Moreover, he says, NNSs are constantly moving along their interlanguage continuum “... as long as they learn-to-use / use-to-learn English" (p. 342); but they can never achieve the competence a native speaker has. Medgyes says that a very few NNSs come close, “...but sooner or later they are halted by a glass wall” (p. 342).

Attempting to clarify the issue of differences between native and nonnative speaker teachers, Reves and Medgyes (1994) carried out a study including teachers from ten countries. The researchers administered a questionnaire with questions about personal background, teaching load, level of students, class size, their self-perception, and so on to 216 subjects $-\mathrm{ESL} / \mathrm{EFL}$ teachers. By choosing subjects from various countries, Reves and Medgyes aimed at putting the NS/NNS issue in an international setting. The researchers' intent with the survey was threefold. First, they wanted to find out about the 
differences in teaching behavior between NSs and NNSs; second, if there are differences, they are largely due to language proficiency; and third, if there are differences in language proficiency, does the awareness of these differences affect NNSs' selfperception and teaching attitudes.

As posited by Reves and Medgyes (1994), "teaching EFL/ESL necessitates both oral and written proficiency, the appropriate use of English in various social situations and at a level far above the learners' proficiency level" (p. 364). Taking into account their findings, the authors maintain that due to “...relative English-language deficiencies, nonNESTs [NNS teachers] are in a difficult situation: by definition they are not on a par with NESTs [NS teachers] in terms of language proficiency" (p. 364). Moreover, Reves and Medgyes argue that the degree of self-consciousness of NNSs depends on how proficient they are in English. As stated by the authors: "It has been shown that the higher the nonNESTs' [NNS teachers'] proficiency level in English, the less self-conscious, hesitant and insecure they will be" (p. 364). Also, the NNSs who had had more frequent contact with native speakers or had spent more time in countries where English is spoken had “...acquired a wider range of vocabulary, a more fluent ease of expression and a more authentic communicative appropriateness than their less fortunate colleagues" (p. 364).

Medgyes (1992), on the findings of the survey that he and Reves conducted, states that there are several common areas of language difficulties among nonnative speaker teachers. Despite the fact that every NNS has his or her own idiosyncratic problems related to the use of English, Medgyes maintains that "the most frequently encountered difficulties covered virtually all areas of language use, but especially fluency, vocabulary, pronunciation, listening comprehension, grammar, and idiomatic English" (p. 345). 
Yet Medgyes (1992) posits that that which is perceived as a weakness on one hand is an asset on the other. The author points out several positive aspects which he considers attributes of nonnative teachers. He argues that: a) only NNS teachers can serve as models of successful learners of English because they are learners of English themselves; b) NNS teachers can teach the strategies they have used effectively in their own learning of English; c) NNSs can provide learners with more information on how the English language works because of all the insights and knowledge they have gathered in their learning process; d) an experienced NNS teacher can anticipate language difficulties; hence be able to help learners overcome their difficulties; e) NNS teachers can be more empathic to needs and problems learners have. Since NNSs are permanent learners of English themselves, they face problems similar to those of their learners; yet at a higher level; and f) only NNSs can benefit from sharing their learner's mother tongue. Medgyes (1992) maintains that "In a monolingual setting, the mother tongue is an effective vehicle of communication in the language classroom, which can facilitate the teaching/learning process in countless ways" (p. 347). According to the author the weaknesses of NNS teachers are balanced out with their own strengths. Thus, argues Medgyes (1992), native teachers and nonnative teachers "...can be equally effective..." (p. 347) in the classroom.

Needs.

Besides the fact that some authors (e.g. Medgyes, 1992; Reves \& Medgyes, 1994; Milambiling, 1999) have described both the weaknesses and the strengths of NNSs, other researchers have focused on needs and concerns of these professionals as well as those of trainees. Doff (1987) states that a rusty or poor command of English undermines the 
teacher's confidence in the classroom; and, consequently interferes with his/her selfesteem and professional status. The needs and concerns of NNSs are translated into weak performance of these instructors in the classroom. As Cullen (1994) points out, many of these needs arise from the "...propagation and increasing acceptance around the world of the principles of communicative language teaching [CLT]" (p. 162). There is now a need, more emphasized than before the spread of CLT, for teachers to have fluency in English in order to "...use it naturally and spontaneously in the classroom" (p. 162). Harmer (1991) maintains that competent language users are those who have not only grammatical competence, but also the other three areas that entail communicative competence. That is, they know how to use the language in different situations, and they have strategic competence as well as discourse competence. As stated in Reves and Medgyes (1994): “...efforts have to be made to improve the non-native English-speaking teachers' command of English to the utmost, to minimize the deficiencies so as to approximate their proficiency, as much as possible, to that of the native English-speaking teachers" (p. 364).

Cullen (1994) points out some needs of NNS instructors. The author reports on a survey questionnaire Berry (1990) administered to secondary school English teachers in Poland. Berry (as cited in Cullen, 1994) asked the respondents to rank the components of methodology, theories of language learning and teaching, and language improvement, according to what they believed they needed the most. The participants ranked language improvement as the most important, methodology as second, and theory as third. Cullen (1994) did not find the results surprising. The contact these teachers have with native speakers and the target language culture is very limited. For most respondents, their only 
contact with the language is listening to English language radio stations and hearing their students talking.

Cullen (1994) suggests that with the advancement of Communicative Language Teaching the needs of NNS teachers have increased, since this approach requires that teachers be proficient users of the language they teach. The author proposes "...a way of addressing the issue of language improvement on in-service teacher training programmes in parts of the world where there is a clear need and a desire for it" (Cullen, 1994, p. 172). Cullen's proposition focuses on language improvement. Also, his methodology component is practice-driven rather than theory-driven, and it uses discussion sessions as a means to evaluate events that happened during the lessons. Rose (1997) reiterates that NNS teachers need language improvement. In an article on the development of pragmatic competence in the classroom, Rose (1997) focuses on the linguistic deficit of NNS teachers. The author states that most of the English-language usage and teaching of speech acts that goes on in the classroom are based on native-speaker intuitions. Nevertheless, this native intuition is not available to the NNS teacher. Rose (1997) argues that by “....sensitizing teachers to context-based variation in language use and the variables that help determine that variation" (p. 132), they would be able to do the same for their learners.

Likewise, Liu (1998) states that "Another area where international TESOL students' needs have been overlooked is their lack of English proficiency required for success in their future teaching" (p. 7). He acknowledges that most of these students have a commendable knowledge of English, particularly grammar. However, “...not many of them have a good grasp of the use of the language" (p. 7). Given the great 
importance that language improvement plays in ESL/EFL teaching, researchers call for the incorporation of language development in TESOL programs. Murdoch (as cited in Liu, 1998) contends that “...the most valued aspect of a non-native English teacher's competence" is a high level of proficiency in the language (p. 7).

Language difficulty seems to be a common problem among nonnative speaker ESL teachers. Greis (1984) says that the needs of NNS trainees enrolled in TESOL programs in the United States are linguistic, cultural and academic. Greis (1984) suggests that in order to accommodate these needs, “...careful consideration [should] be given to the selection of required course work, to the adoption of methodology and to the provision of adequate practice teaching" (p. 322).

A similar opinion is held by Polio and Wilson-Duffy (1988). The authors carried out a study with three international students enrolled in an MA TESOL program in North America. The researchers' aim was to determine the concerns and difficulties that international students encounter in the teaching practicum component of the program. In order to do that, the researchers followed the three students through their teaching practicum. One of the main concerns of one of the participants was her language skills, particularly with slang or idioms featured in the authentic materials. The second participant generally “...did not worry about his English proficiency...” (p. 26), for he knew from his experience that all the international students made mistakes, and the students preferred NS teachers. His main concerns, however, were spelling and vocabulary. As for the third participant, she was concerned about learning more about teaching methodologies, and improving her own English. Polio and Wilson-Duffy (1998) maintain that the trainees' "...concerns were similar to those of all preservice teachers" 
(p. 27). Moreover, they were afraid of not being understood by their students. Cultural problems, such as U.S. classroom management, and late students were also a concern. In addition, “...they were afraid of the ESL students' attitude toward being taught by a NNS" (p. 27).

Kamhi-Stein (2000) also addresses the needs and areas of concern of NNS teachers and teachers-in-preparation, and summarizes these issues as falling into four general categories: " 1 . low confidence and self-perceived challenges; 2 . self-perceived language needs; 3. lack of voice and visibility in the TESOL profession; 4. Self-perceived prejudice based on ethnicity or nonnative status" (p. 10). In addition, the author presents a rationale to address these needs and concerns in MA TESOL programs in the United States. Kamhi-Stein (2000) suggests that there be a cross-curricular approach. That is, "in this approach activities addressing issues related to NNSs are integrated across the TESOL MA program curricula" (p. 11). Kamhi-Stein (2000) argues that both NNS and NS teachers-in-preparation would benefit from this approach through mutual help because both categories “...have much to learn from each other" (p. 13). In addition, this new approach prevents NNS students from isolating themselves. Hence, they would “...see their concerns and interests as an integral part of the TESOL MA program curriculum" (p. 13).

Following the controversy on the qualifications of both NS and NNS teachers, some authors have voiced their opinions about desirable characteristics of successful teachers - regardless of their statuses as NSs or NNSs. As Medgyes (1992) points out, "The concept of 'the ideal teacher' is not one reserved for either category [NS/NNS]" 
(p. 348). The author holds that in a native/nonnative relation, the ideal NS teacher is the "...one who has achieved a high degree of proficiency in their learners' mother tongue" (p. 348). The ideal ESL/EFL teacher, Medgyes says, “.... is the one [NNS] who has achieved near-native proficiency in English” (p. 349). Astor (2000) argues that "a qualified teacher of English should be a professional in at least three fields of knowledge: pedagogy, methodology, and psycho- and applied linguistics" (p. 19). The author holds that these qualifications are essential for a teacher to be successful in the classroom. Milambiling (2000) maintains that language teachers should be multicompetent linguistically and culturally, stating that "Multicompetence should therefore be a goal for all language teachers, whether or not their mother tongue is a world language, as English is" (p. 326).

Another pertinent dimension of research on the dichotomy of native speakers and nonnative speakers is how their teaching situations differ in the ESL and EFL settings. However, I want to confine my discussion primarily to the ESL setting.

In spite of extensive research on a number of issues relate to nonnative speaker teachers of English, it appears that few studies have investigated how ESL learners view these professionals. Most authors have who have dealt with this topic have drawn on the teachers' perspective of how their students see them. In view of this, in the present study I seek to investigate how ESL learners perceive their nonnative speaker teachers. 


\section{Chapter 3}

Design and Methodology

The review of the related literature shows an increasing number of articles which deal with issues related to NNS teachers of English. Research has shown how NNS teachers are seen by themselves and their perceptions of how they are viewed by their students. Despite being related to students' views of NNS teachers, the present study differs from previous research concerning ESL students' perceptions of their nonnative speaker teachers. Whereas in previous studies researchers drew on the teachers' assumptions of how ESL students saw them, in this study I investigate the issue of students' perceptions from their points of view.

In this chapter, a detailed description of the design and methodology is provided. In addition, I explain why I chose to carry out a qualitative study, rather than a quantitative one. Furthermore, I present information regarding both the students and the two instructors who participated in the study.

\section{Research Question}

The research done on the literature related to nonnative speaker teachers of English and my own interest in the topic have led to the following research question: How do ESL students perceive their nonnative teachers?

\section{Qualitative Research}

Since the topic of this investigative study is students' perceptions of nonnative ESL teachers, I chose to carry out a qualitative study. As Marshall and Rossman (1999) state "...qualitative research is pragmatic, interpretive, and grounded in the lived 
experiences of people” (p. 2). In addition, Rossman and Rallis (as cited in Marshall \& Rossman,1999) say that this kind of research “...takes place in the natural world [and] ...uses multiple methods that are interactive and humanistic" (p. 3). Based on the assumptions of qualitative research, the methods of data collection chosen for this study were class observation, interviews with the participants, and a questionnaire. These three data sources allowed me to triangulate the findings.

\section{Setting}

The study was conducted in the intensive English program of a major land-grand institution in the Appalachian region of the United States. The IEP at the State University employs both native and nonnative speakers of English. At the time this study was conducted, there were eight NNSs and 12 NSs of English. Classes in the IEP are assigned according to the instructors' wishes, availability, experience and the needs of the program. The students enrolled in the program have an orientation session before classes start. During this orientation, the students are informed that they will be taught by people from various parts of the world. The directors of the intensive English program emphasize during the orientation that having NNS instructors is beneficial to their aural practice since they will use English to communicate with both NSs and NNSs.

The intermediate classes were held in the building where most of the IEP classes were conducted. The classroom was rather small for the eight participants, the instructor, three other students who did not took part in the study, and me. The desks were arranged in a horseshoe shape with the instructor's desk between the two ends. The chalkboard was behind the instructor, and the air conditioner was set in a big window. Although the 
windows were always kept closed because of the noise from the street, there was enough light in the room.

The advanced group met in a comfortable, bigger, carpeted room in another building. This room was equipped with a TV and a VCR. The desks were set in a semicircle with the instructor's desk in the middle, and the chalkboard behind it. Two light fixtures and the natural light that came in through two big glass windows lighted this room.

\section{Recruiting the Participants}

The teachers who took part in the study were contacted by me in their offices, where I explained to them the procedures of the study and asked them to sign a consent form. Next, I met with the students in their classrooms, where I explained to them what the project entailed, and invited them to take part in it. The recruiting of participants was done following the guidelines established by the State University Institutional Review Board for the Protection of Human Research Subjects.

Each participant received a consent form, which contained information about both the research and the researcher. This consent form (Appendix C) was then read to them by me. After I explained the study and read the form, the students were allowed some time to ask questions to clarify points that were not clear to them. Next, the students signed the consent form and were told that they would receive a copy on the following day. Also, the participants were told that their participation was voluntary; so there would be no compensation for taking part in the study. 


\section{Participants}

The participants in the study were 16 students enrolled in the Intensive English Program (IEP) at the State University. The students chosen for this study were divided into two groups: an intermediate and an advanced group. They were placed in these groups based on their Michigan Placement Test and the Test of English as a Foreign Language (TOEFL) scores.

The scores required for admission to the intermediate level of the IEP range from 35 to 54 on the Michigan test, and 350 to 409 on the TOEFL test. This group was made up of four males and four females; all of whom were enrolled in a grammar class taught by a NNS. They were from diverse language backgrounds: Arabic, Persian, Brazilian Portuguese, and Spanish. Their ages ranged from 18 to 32 and older.

In order to be in the advanced group, the students had to score between 80 and 100 on the Michigan test, and between 500 and 550 on the TOEFL test. Nevertheless some students in the advanced group had scores higher than 550. The members of the advanced group were all enrolled in a writing class, also taught by a NNS. They were six males and two females. The language background in this group was also varied: Arabic, Brazilian Portuguese, Japanese, and Spanish. Their age range was between 18 and 32.

In addition to the students, the two instructors in charge of the groups also participated in the study. The teacher who taught the intermediate group is a native speaker of Turkish, in her mid-twenties, who has lived in the United States since 1995. She holds a master's degree in TESOL, and has taught ESL since 1995. In addition, she has taught English literature and EFL in Turkey for one year. The teacher in charge of the advanced group is a native speaker of Brazilian Portuguese, also in her mid-twenties, 
who has lived in the United States since 1993. She was a graduate student in her last term of a TESOL master's program and had taught ESL for three years at the time of the study.

\section{Observations}

My objective in doing class observations was to seek recurring patterns of behaviors and attitudes pertinent to this research project because, "Through observation, the researcher documents and describes complex actions and interactions" (Marshall \& Rossman, 1999, p. 107). Since it is in the classroom that most of the learner-instructor interaction takes place, I found this method of data collection relevant to this study.

The groups I observed had different schedules. The intermediate group met for their grammar class five times a week for 50-minute classes. The advanced group, however, had three weekly meetings of 1 hour and 50 minutes each for their writing class. The observations were conducted from April $1^{\text {st }}$ through April 22 $2^{\text {nd }}, 2002$. A total of 10 hours of class were observed in the intermediate group. In addition, 11 hours of class observations were conducted in the advanced group. Although it was not possible to go unnoticed, I would enter the classroom before the class started so as not to disturb the setting. During the observations, I took notes on the students' behaviors and on the interaction between the instructors and the students.

\section{Questionnaire}

The students were asked to answer a questionnaire (Appendix D) during the first week of class observations. This questionnaire was composed of 23 questions written in English. Some of them were open-ended, and others had options from which the students could choose. Moreover, the questionnaire encompassed demographic questions as well 
as questions about students' perceptions of both NS and NNS teachers. The questionnaire served two purposes. First, it enabled me to derive a profile of the students. Second, it generated data that could be cross-checked with the data provided by students in the interviews and observations.

Interviews

The interviews took place during the last two weeks of class observation, and were conducted in English. However, the English level of the dialogue was simple, due to some students' limited level of proficiency in English - particularly the students in the intermediate group. The purpose of the 20 open-ended questions in the student interview (Appendix E) was twofold. First, along with the questionnaire, it allowed me to build a profile of each student. Second, it served as one source of data regarding how the students perceived nonnative teachers of English. The participants in the study were interviewed in the researcher's office. These interviews lasted approximately 20 minutes each, and were tape-recorded and then transcribed. The teacher interviews featured questions related to their teaching experience, and classroom issues associated with NNSs (Appendix F). One of the teachers was interviewed in her office; and the other, via e-mail.

In summary, sixteen ESL students and their two NNS instructors participated in the study. The data were collected through class observations, a questionnaire, and interviews. The class observations were conducted from April $1^{\text {st }}$ to April $22^{\text {nd }}, 2002$. The students answered the questionnaire in the first week of class observations, and were interviewed during the last two weeks of observations. 


\section{Chapter 4}

\section{Findings}

In this chapter, I report on the findings pertaining to the student participants' perceptions of their nonnative instructors. The sources of data collection used in this study allowed me to gather information, which was grouped into five categories: students' perceptions of nonnative speaker teacher's characteristics; ESL students' preferences; NNS teacher credibility; nonnative speaker teachers as models; and previous experiences with nonnative speaker teachers. The information presented in this chapter derived from the participants' responses to the questionnaire, the observations, and the interview. However, the interviews with the two nonnative instructors also provided me with important data. In spite of the fact that the student participants in the study were of two distinct levels of English proficiency, I present the findings that came from the two groups together. This was done because the categories that emerged from the data are the same for both groups. However, the students' opinions are not always compatible. From these data, I drew my focus towards the information that enabled me to answer the research question posed earlier: how do ESL students perceive their nonnative teachers?

Since this is a qualitative study, I find it necessary for the reader to become acquainted with the student participants. In view of this, some information about the participants in the study is summarized in Tables 2, 3, and 4. Their names have been replaced by pseudonyms to assure anonymity. In addition, it should be added that all the quotes excerpted from the students' interviews and questionnaires are authentic 
reproductions of what they said or wrote. That is, no corrections of students' errors were made. 
Table 2

Summary of Students' Gender, Age, and National Origin

\begin{tabular}{lcccc}
\hline $\begin{array}{l}\text { Intermediate } \\
\text { students }\end{array}$ & Gender & Age range & Country & Mother tongue \\
\hline Ahmed & M & $18-24$ & Saudi Arabia & Arabic \\
Ana & $\mathrm{F}$ & $18-24$ & Venezuela & Spanish \\
Carlos & $\mathrm{M}$ & $18-24$ & Colombia & Spanish \\
Fatimah & $\mathrm{F}$ & $18-24$ & Saudi Arabia & Arabic \\
Francisco & $\mathrm{M}$ & $18-24$ & Venezuela & Spanish \\
Gloria & $\mathrm{F}$ & $18-24$ & Venezuela & Spanish \\
Marta & $\mathrm{F}$ & $35-40$ & Brazil & Portuguese \\
Nasser & $\mathrm{M}$ & $18-24$ & Iran & Persian \\
\hline \multicolumn{1}{c}{ Advanced } & & & & \\
\multicolumn{1}{c}{ Students } & & & & \\
& & & & \\
\hline Abla & $\mathrm{F}$ & $18-24$ & Kuwait & Arabic \\
Fahad & $\mathrm{M}$ & $18-24$ & Kuwait & Arabic \\
Luci & $\mathrm{F}$ & $18-24$ & Venezuela & Spanish \\
Pablo & $\mathrm{M}$ & $18-24$ & Peru & Spanish \\
Renato & $\mathrm{M}$ & $18-24$ & Brazil & Portuguese \\
Ricardo & $\mathrm{M}$ & $25-32$ & Brazil & Portuguese \\
Takeshi & $\mathrm{M}$ & $25-32$ & Japan & Japanese \\
Victor & $\mathrm{M}$ & $25-32$ & Colombia & Spanish \\
\hline
\end{tabular}


Table 3

Summary of the Intermediate Students' Educational Background and Nationalities of their Previous NNS Teachers

\begin{tabular}{|c|c|c|c|}
\hline $\begin{array}{l}\text { Intermediate } \\
\text { students }\end{array}$ & $\begin{array}{l}\text { Years studying } \\
\text { English }\end{array}$ & $\begin{array}{l}\text { Schooling/ } \\
\text { profession }\end{array}$ & $\begin{array}{c}\text { Nationalities of previous } \\
\text { nonnative teachers }\end{array}$ \\
\hline Ahmed & 1 year & $\begin{array}{l}\text { High school } \\
\text { graduate }\end{array}$ & $\begin{array}{l}\text { American, Brazilian, English, } \\
\text { Saudi Arabian, Turkish }\end{array}$ \\
\hline Ana & 1 year 3 months & Lawyer & $\begin{array}{l}\text { American, Brazilian, Turkish, } \\
\text { Venezuelan }\end{array}$ \\
\hline Carlos & 10 years & $\begin{array}{l}\text { High school } \\
\text { graduate }\end{array}$ & $\begin{array}{l}\text { American, Brazilian, } \\
\text { Colombian, Turkish }\end{array}$ \\
\hline Fatimah & 4 years & $\begin{array}{l}\text { BA in } \\
\text { English }\end{array}$ & $\begin{array}{l}\text { American, Egyptian, Saudi } \\
\text { Arabian, Turkish }\end{array}$ \\
\hline Francisco & 1 year 4 months & Dentist & $\begin{array}{l}\text { American, Brazilian, Turkish, } \\
\text { Venezuelan }\end{array}$ \\
\hline Gloria & 6 years & $\begin{array}{l}\text { High school } \\
\text { graduate }\end{array}$ & $\begin{array}{l}\text { American, Brazilian, Turkish, } \\
\text { Venezuelan }\end{array}$ \\
\hline Marta & 5 years & $\begin{array}{l}\text { MA in } \\
\text { Psychology }\end{array}$ & American, Brazilian, Turkish \\
\hline Nasser & 1 year & $\begin{array}{l}\text { High school } \\
\text { graduate }\end{array}$ & $\begin{array}{l}\text { American, Brazilian, English, } \\
\text { Iranian, Turkish }\end{array}$ \\
\hline
\end{tabular}


Table 4

Summary of the Advanced Students' Educational Background and Nationalities of their Previous NNS Teachers

\begin{tabular}{|c|c|c|c|}
\hline $\begin{array}{l}\text { Advanced } \\
\text { students }\end{array}$ & $\begin{array}{l}\text { Years studying } \\
\text { English }\end{array}$ & $\begin{array}{l}\text { Schooling/ } \\
\text { profession }\end{array}$ & $\begin{array}{c}\text { Nationalities of previous } \\
\text { nonnative teachers }\end{array}$ \\
\hline Abla & 10 years & $\begin{array}{l}\text { High school } \\
\text { graduate }\end{array}$ & $\begin{array}{l}\text { American, Brazilian, Egyptian, } \\
\text { Kuwaiti, Syrian }\end{array}$ \\
\hline Fahad & 4 years & $\begin{array}{l}\text { High school } \\
\text { graduate }\end{array}$ & $\begin{array}{l}\text { American, Brazilian, Egyptian, } \\
\text { Kuwaiti, Moroccan }\end{array}$ \\
\hline Luci & 7 years & $\begin{array}{l}\text { Psychology } \\
\text { student }\end{array}$ & $\begin{array}{l}\text { American, Brazilian, } \\
\text { Guyanese, Polish, Turkish, } \\
\text { Venezuelan }\end{array}$ \\
\hline Pablo & 3 years & Engineer & $\begin{array}{l}\text { American, Brazilian, English, } \\
\text { Korean, Peruvian, Turkish }\end{array}$ \\
\hline Renato & 7 years & $\begin{array}{l}\text { Student of } \\
\text { Economy }\end{array}$ & $\begin{array}{l}\text { American, Brazilian, Chilean, } \\
\text { English, S. African }\end{array}$ \\
\hline Ricardo & 4 years & $\begin{array}{l}\text { Business } \\
\text { administrator }\end{array}$ & American, Brazilian \\
\hline Takeshi & 11 years & $\begin{array}{l}\text { Business } \\
\text { administrator }\end{array}$ & American, Brazilian, Japanese \\
\hline Victor & 3 years & Journalist & $\begin{array}{l}\text { American, Brazilian, } \\
\text { Colombian, English, French }\end{array}$ \\
\hline
\end{tabular}


In the Intensive English Program, where this study was conducted, the students have an extensive skill and content-based curriculum. The variety of classes that the students have in the IEP include: American Culture, Communication Skills, Writing/ Study Skills, Grammar, Reading/Vocabulary, TOEFL Preparation, and some optional classes such as English through the Arts and Business English. Since the IEP at the State University employs both native and nonnative speakers of English as teachers and graduate assistants, classes there are taught by both. As previously mentioned, classes are assigned to teachers according to the teachers' wishes, experience, availability, and the needs of the program.

For a better understanding of the findings, I find it necessary to provide the reader with some information on the interaction between the two instructors and their students. Deniz, the instructor of the intermediate group was a friendly, easygoing, yet not lenient, teacher. Every activity was done in a fast pace and the students seemed to be accustomed to that. In spite of the group fast pace, Deniz always encouraged the students to ask questions. She was in control of the class and the students seemed to like that. She always kept a positive attitude in class. During the in-class observations, I was able to see that the students were assigned homework on a daily basis. Although they sometimes complained about their workload, their complaints had a joking tone. They seemed to be very appreciative of their teacher's assigning a lot of homework. Despite the fact that this was a teacher-centered class, and that there was not much time for student-student interaction, the students always found time to make a joke or praise a classmate for answering a question correctly. The general atmosphere in the class was very pleasant. 
The students' liveliness and attentiveness demonstrated that they were interested in the subject being taught and they had a very good rapport with the instructor.

In the advanced group, there was a lot of student-student interaction as well as teacher-student interaction. The students usually worked in two big groups of four students each. The atmosphere in both groups always seemed to be pleasant. The instructor had a positive attitude in class and constantly tried to keep the students involved, but they did not seem to be very interested. Oftentimes, the students would digress from the topic they were discussing and start talking about something else. They often left to go to the restroom or drink water. With the exception of a few students, this group was not as lively as the intermediate one.

\section{Students' Perceptions of Nonnative Speaker Teachers' Characteristics}

The class observations and the ESL students' answers to the questionnaire and in the interviews demonstrated that, when it comes to identifying a NNS, some characteristics play a decisive role. The most common characteristics that the intermediate and the advanced students mentioned in their comments were accent, physical appearance, names, and different clothing styles.

The intermediate group relied mostly on the accent of the instructors in order to judge whether or not they were native speakers. Although this was an intermediate group, seven out of the eight subjects reported that they were able to perceive a difference in the way nonnative teachers and native teachers talk. Ana, for example, said, “...we can always [tell] because of the accent. Sounds different, like us." Similarly, Fatimah stated that the nonnative teachers that she had met "...have the Egyptian accent or Pakistani accent. Even here, Deniz have a Turkish accent. So I can recognize her. If she, any 
teacher, speak with me, I can identify from her accent, the pronunciation to the words." Despite their limited knowledge of English, the students in this group could tell there was a difference.

In addition to mentioning accent as a means to denote nonnativeness, students mentioned two other indicators: clothes and names. One student stated that the dressing styles of the nonnative teachers differ from those of the native teachers. He said he was able to recognize a NNS teacher "... for the way that the teacher speak or wear the clothes. And the pronunciation of the words, I know [they are not from here].” Besides mentioning accent, Carlos reported: “...I can [tell] for the pronunciation, or the name. If their name is weird, I realize - oh, this guy is not from here; they don't have that kind of name here. Maybe, more common names, yes."

The comments made by two participants in the intermediate group suggest that the teacher's appearance, along with the accent, can help them determine whether or not an instructor is a NNS. As Nasser stated it,

...some teachers I know, they look like from somewhere. But other teacher, you know, because from here, they talk and you can understand they are from here. And some teachers, you have a teacher, you see he or she and you know they are not from the United States; sometimes because of the appearance, sometimes because of the voice.

By claiming that she could discern the accent of speakers of the same heritage as hers, Gloria went one step further. She said, "Depends of the accent, or physically. I can identify the Latin people because of the accent." 
On the other hand, Ahmed relies solely on the looks of the instructor. He stated that the looks of these two groups - NS and NNS - are discernible. His comments were: “...[if] he or she look like from another country, I know;" and "...sometime if he/she look like native or no if is elebant [elephant]." I asked the student what he meant, and he said that most Americans he knew were overweight, “...like elebant.”

Having reported on the intermediate students' perceptions, I now turn to the advanced group. The comments made by the students in the advanced group shows that there are more similarities than differences between the comments made by the two groups. The advanced group, too, relied on the instructor's accent and looks in order to determine his/her nonnativeness.

Three out of the eight advanced respondents to the questionnaire and to the interview explained that they can definitely identify nonnative speaker teachers after hearing them talk. Abla stated that "...they [teachers] should talk first. If they talk, I can know if they are native or nonnative." Concurrently, Pablo said that he could definitely tell if a teacher is a NNS because of the teacher's accent. Some students seemed to be aware of the fact that the majority of the NNS teachers will always have some kind of accent. Renato noted: “...the accent - it sounds different. Even if the teacher is here for a long time, you can know; you can detect he is not from here."

Two subjects, however, recognized the fact that some accents are stronger than others. As Fahad and Takeshi explained, it is not always that they are able to spot an accent. They both believed that sometimes it is possible. As Fahad noted, "It depends on the accent." Furthermore, Fahad informed me that he believed Arabic speakers have a thick accent when they speak English. Therefore, it is easy for him to perceive the accent 
if the speaker comes from a country in the Middle East. Concurrently, Takeshi expresses that sometimes he can tell the teacher is a nonnative speaker of English. He said, "Sometimes I can; especially the teacher who speaks Spanish as the first language. They have an original accent I didn't experience, I had never experienced in my life. When they speak English, they have a kind of Spanish accent.”

Similar to the intermediate group, the more advanced students seemed to rely on the instructor's looks in order to be able to tell whether or not he/she is a nonnative speaker of English. Victor said he could tell a teacher is a NNS solely because of his/her appearance. Victor said, “...just for his appearance because the color of the hair here, the eyes [are different]... physical appearance; but not other things." It appears that Luci shares Victor's perceptions. Luci noted that she could tell that a teacher is not a native speaker of English “...from the physical appearance. However, in USA, you know, there a lot of cultures and stuff, and they can be a second generation of people that came here." ESL Students' Preferences

The ESL students' preference for native or nonnative instructors does not seem to be a hard-and-fast rule. The students' various opinions reflected in their comments are presented here. Marta said: “No preference because I don't see difference about the teaching; about the pronunciation of words, yes. But about the teaching, it's no difference." Likewise, Francisco argued: "I don't care what kind of teacher. I care the teacher be a good teacher, or explain good the class and my questions." Ana agreed with her classmates' ideas. She pointed out that “It doesn't matter. If...they know English, I don't care. For example, if you're here teaching and speaking with me, is because you know English, and I don't care. I can understand, I know.” 
It seems that the topic of preference was rather confusing to the students. Ana appeared to have mixed opinions about it. As she went on, she pointed out, "But I prefer sometimes a nonnative speaker because they explain better. They use better words, I don't know; they explain the ideas. But with the other ones... with the native speakers, I don't know...." Also, Ana claimed that nonnative speaker teachers could help her with strategies to learn the language. She wrote that she would prefer a NNS instructor for her TOEFL preparation classes, grammar, and writing classes. The reason for that was, "Because they [NNS] know the strategies, the importants details that we have to know to improve our English.”

According to three other students, the status of the teacher, be it native or nonnative, does not play a role when it comes to preference for having them as instructors. Nevertheless, some of their other comments seemed to contradict their professed lack of preference. They said they would prefer to have a NNS for some specific areas - grammar, TOEFL preparation, and writing. For example, Carlos stated:

I think it's the same. But my grammar class is a very good class. Deniz, who is from Turkey, she is a very good teacher. The grammar class is better to be taught by a nonnative teacher because is better. She can understand very well the grammar questions because she studied that. But the native teachers, maybe they don't know the grammar.

Carlos made yet another statement. He pointed out that "Nonnative speakers can teach better than the native, but the native speakers are very important for pronunciation and the understanding of slangs and the different vocabulary." 
Gloria seems to share Carlos' preference for NNS grammar teachers, noting that “Grammar, I don't know, I have [had] this experience with a nonnative, with Deniz. She is a nonnative speaker and she explain very well. She knows everything. I had this experience with a native and nonnative." Conversely, Gloria also mentioned that with native speaker teachers, "it [is] more easily and your language will be perfect but this not happen all the time." Unlike Carlos and Gloria, Nasser prefers having a native speaker as his grammar teacher. In addition, he mentioned another subject for which he prefers to have an NS as instructor. He said: "I think that some subjects, grammar and vocabulary, I think native is better. For other classes, it's not different [having a NS/NNS teacher]."

Ahmed expressed his preference for NS instructors in two subject areas: reading and communication skills. When it came down to other areas, he believed that having a native speaker as instructor was the same as having a nonnative speaker one. Ahmed claimed:

Reading and communication, [I prefer] native speaker because they speak fast, and that's good for listening. And reading, they say the words correct and they read fast. For other classes, no problem; grammar, no problem; writing, no problem. Another class, no problem. Communication skills and reading is important native teachers. The other classes, no problem; it's the same. Contrary to all the mixed opinions reported above, one student asserted that she preferred to have native speaker teachers only. Fatimah, who is a Saudi Arabian with a B.A. in English, asserted adamantly that only NS teachers could provide her with correct instruction: "Only native speakers because in the class they can give me the information and I can...how can I say...I can get the information correctly." On the questionnaire, 
Fatimah also mentioned: "With nativ[e] teacher I can learn and practise the language more than [with] nonnative."

The comments the advanced students made do not differ much from those of the intermediate students. It appears that they, too, tend to have multiple preferences regarding the NS/NNS instructor. This can be seen in the comments excerpted from the students' interviews and their answers to the written questionnaire.

Abla and Ricardo expressed that they do not have any preference for native speakers or nonnative speakers as instructors. Abla stated: "It's the same thing. I mean, here in the United States, for me it's the same because both of them I think are good. I learn from them. I can understand from them. So I think it's the same." Her classmate Ricardo thinks likewise. He said: "Well, as I just said, I think there's no difference. I mean, the teacher's knowledge and the way the teacher teaches, it counts; not if she or he is native or nonnative speaker. It doesn't count for me.”

Takeshi's opinion was divided. However, from his comments, one can see that, for pronunciation or oral communication and the like, he would prefer a native speaker teacher. He said:

I have no preference because when I want to learn speaking, I prefer native speakers. But other areas, I don't have preference at all because when speaking, native speakers know how to speak, or course; and they knew, they don't speak as we do. How can I say, for example, 'a lot of' [each word pronounced separately], they say: 'alotof' [pronounced as a chunk]. But I didn't know this kind of pronunciation before I came [to the United States]. So it is a good 
experience for me. But other areas, like grammar, writing, I think it's no problem by learning from a nonnative teacher.

Also, Takeshi wrote that, for native speakers, American culture, grammar, reading, and vocabulary are instinctive. As he stated, "Native speakers think these skills are instinctive, not by effort." Therefore, he said, he would rather have nonnative speaker teachers for these areas.

Both Luci and Pablo agreed with Takeshi's opinion that having a native speaker for communication skills classes is better. Luci said: "I prefer native speaker for communication skills and pronunciation." Pablo also mentioned that he would prefer to have a native speaker teacher for communication skills because "...they have the accent." Nevertheless, Pablo believed that in other areas, having a native speaker instructor is unnecessary, noting that "in grammar, reading, and writing, it [having a NS teacher] is not necessary."

Victor's response to the questions about preference is another example of how intricate this topic is. Victor stated:

Well, I think it's a difficult question because native speakers are better. But a good mix of both is really good because sometimes native speakers didn't know how to explain you.... in the correct way to learn. And nonnative teacher know this process of the knowledge of the new idiom [language]. And they can explain in different ways and try to figure out what is the problem with you and your accent. They had this same experience; and this is helpful for me.

In addition, Victor stated that he would rather be taught writing, study skills, reading, and vocabulary classes by nonnative teachers. His comments explained his point of view: 
For example, no grammar! Grammar no! Vocabulary and something of writing... class that is related to know more words and expressions, and how to start to talk and develop communication skills. But in communication skills, the native speakers are better; but the nonnative teachers can help you in another classes to improve ways to express yourself in different ways.

Fahad agreed with Victor on the issue of grammar knowledge. By analyzing Fahad's statements, it is clear that his preference changes in accordance with the subject areas he needed to study. He commented: "It depends on the classes. So, like grammar classes, I prefer native speakers because they know more than nonnative speakers, and reading too."

Unlike Victor and Fahad, Renato thinks grammar may be better taught by nonnative speakers. He justified his opinion by saying,

...because I think when, like the nonnative teachers, they have to study a lot and they are prepared; grammar rules are fresh in their minds. They can answer quickly, you know what I mean? I think he is like... more inside the topic than native teachers. To me, I have the impression that native teachers, they use more instincts... like: “I know this; I've been talking this language all my life, and I think that is correct." Sometimes I think they are not sure about the rule. Luci had a more comprehensive opinion about the classes that she would rather be taught by a NNS. Whereas the other students mentioned basically grammar and reading, Luci claimed that having a nonnative instructor to teach grammar, reading, vocabulary, and writing was better. According to Luci, this is “...because they know 
better the grammar rules [and] how to explain meaning of words." Later, she commented on her preferences for nonnative instructors teaching writing:

... I think nonnative teachers know better the grammar rules and the styles and skills than the native speakers because sometimes when you know your native language you just know the language because you were born, you grew with the language. Then you forget the rules sometimes because you learned them in high school.

The last comment about preference reported here is about the TOEFL preparation class. Two students reported that they would rather have a nonnative speaker teacher for this. Fahad mentioned that it is important in order for him to achieve his goals. He said: “...nonnative teachers have experience with TOEFL classes. So they give us ideas to pass the TOEFL; to work on it."

\section{NNS Teacher Credibility}

The notion of credibility of the NNS reported in this chapter was derived from the students' answers to a question directly related to the topic. When the students from the intermediate and the advanced group were asked if they ever tested their NNS teachers, their answers demonstrated the degree of credibility NNS teachers enjoy with these two groups.

The intermediate students' answers to the question showed that the group is divided. That is, four out of the eight students said yes to the question and four said no. Their comments are presented here. Nasser stated that he tested NNS teachers if he sensed that they were insecure. He said, “ ...sometimes I had, you know, a teacher, he 
can't speak very good. So sometimes I have to test him. I have to ask the question." Ahmed's answer, however, was more detailed. He stated:

Sometimes yes. Sometimes when they [NNSs] teach me and I know something before when they come to class. I asked something, they give one answer. Maybe next day, or two days, I ask again or I ask another teacher. But I trust these [NNSs] teachers; they give the answer.

The other two students who responded affirmatively to the question about testing NNS teachers added that the same applies to NS teachers. That is, they test both NNS and NS teachers. For example, Ana reported that

That's true [testing NNS teachers]. Yeah, I did [laughs]. I actually knew the word, the question, the answer. It's just to reaffirm what I know, or just for prove they know. I do the same with native speakers because I want to show them that I know words that they don't know (laughs). Like this week, I knew that word: 'ousted', o-u-s-t-e-d. And nobody knew that. That was funny. Francisco's attitude is similar to Ana's. Francisco also pointed out the fact that he used vocabulary to test his instructors. He said: "Yeah [laughs]. When there's a verb that have different meanings or another way, I ask the teacher [NNS] for the other meaning. I do the same with native teachers, about verb, about vocabulary."

During the observations, there was one instance in which a student asked the instructor questions about the meanings of two phrasal verbs. Although the student's questions were not related to the activity that the class was engaged in, and were completely out of context, there was no evidence for me to determine if her questions were legitimate or simply a device to test the instructor. 
Only one of the four subjects who stated that they did not ask their NNS teachers questions to test them gave a reason why she did not do that. Fatimah claimed she did not do so in order to spare the instructor from embarrassment. She said: "No, I don't want to embarrass them." The other three subjects simply gave a negative answer to the question.

Although four students in the intermediate group said that they did test their NNS speaker teachers, it appears their instructor never realized that. Deniz, the instructor in charge of the intermediate group said that she never felt as though her students were challenging her knowledge of English. She wrote: "Phrasal verbs and prepositions - I am not an expert on them, but I never felt that I was challenged [by a student].”

Furthermore, Deniz stated that if they ask her a question to which she does not know the answer, she tells them that she will find the answer. She said

If they ask me something that I do not know, I would always confess it. I never try to come up with a close explanation as an answer if I am not sure. Therefore, I simply say, "I do not know the answer", but it is my responsibility to do my research, find the answer, and bring it to the class. And I am very careful about it. I always provide the correct answer the next class to them.

It appears that the more advanced the students were in this study, the less likely to be skeptical of their instructors' linguistic knowledge they were. Whereas in the intermediate group half of the students admitted to having tested NNS teachers and the other half said they did not, in the advanced group the large majority said they only asked legitimate questions. Seven out of the eight participants enrolled in the advanced group said they never asked questions in order to confuse or test their NNS teachers of English. 
Contrary to his classmates' unanimous answers, Victor's answer was positive. He said he did test his NNS instructors. However, he pointed out that he only did that in the EFL context, "In Colombia; but not here."

Mariana, unlike Deniz, felt that the students in the advanced group sometimes checked her knowledge. Mariana explained:

I recently had a student that gave me a couple of those examples. I think, most of the times, the students challenge your knowledge when you seem unsure of what you're doing. And maybe that was the case, because I was. One situation was on a peer review session that we had in the beginning of the semester. The student gave a few examples in the paragraph to support his idea. And the examples were not clear. And they didn't relate directly to the idea he was trying to express. And I observed that... and it was an oral peer review; so maybe that would have been a problem as well; that might have influenced. And I expressed to him that, you know, was not an appropriate example; and he kept challenging me, saying that yes, it was, and maybe I wasn't sure of what he was reading, and he read the example a couple of times trying to challenge me that maybe I wasn't understanding what he was reading because, for him, the example was related. So at that point, I simply said "OK, you know, if you...ultimately, the paper is yours. If you're comfortable with this example, that's fine. You know, but in my opinion as your teacher, and with my experience, I can say that maybe another example would be more appropriate." So at that time, I felt like maybe if it was a native speaker, he would have felt that that person had a better authority to say "no, that example is not related to that idea." 
The other example Mariana reported was related to spelling:

And another situation was when we, in vocabulary, you know, like when they ask me. My students usually ask, "How do you spell this?”, "How do you spell that?" I usually have a dictionary in class, but not all the time. Sometimes I forget. So, when there are certain times when I don't know how to spell something, the other students in class, I usually say, "Well, I'm not sure how to spell that." And then we try to work at it with other students in the class. And then, you know, some students will say: "Well, I think it's with two l's" or "two p's", or whatever the situation may be. And I would say: "Well, maybe. I don't think so." You know, so we kind of work on it together. And I think that, because I'm not sure of the spelling when I say: "I think it's spelled this way," they challenge that completely. They say: "Well, I don't know." They look it up in their electronic dictionaries, or... But I usually look up the word in the dictionary and bring it back to class the next session. So, I mean, I don't feel uncomfortable, myself, with those kinds of situations because I know that it's not the teacher's obligation to know everything; and I'm not the best speller. So I don't know all of the spelling of the English words. But I think students challenge me more because they know that I'm a nonnative speaker. And that's the downside of it; but I think in many ways it's positive.

Although Mariana felt that the students tested her on her knowledge of English, I did not observe anything that would corroborate her opinion. All of the questions posed by her students during the observations were pertinent to the topic being discussed in class. 


\section{NNS Teachers as Models}

It seems that the majority of the students, both in the intermediate and in the advanced group, see their NNS teachers as models to follow. This information is summarized in Table 5. 
Table 5

NNS Teachers as Models

\begin{tabular}{lll}
\hline \multicolumn{1}{c}{$\begin{array}{l}\text { Intermediate } \\
\text { students }\end{array}$} & Yes & No \\
\hline Ahmed & & $\mathrm{X}$ \\
Ana & & \\
Carlos & $\mathrm{X}$ & \\
Fatimah & $\mathrm{X}$ & $\mathrm{X}$ \\
Francisco & $\mathrm{X}$ & \\
Gloria & $\mathrm{X}$ & \\
Marta & & $\mathrm{X}$ \\
Nasser & $\mathrm{X}$ & \\
\hline \multicolumn{1}{c}{ Advanced } & & \\
$\quad$ students & Yes & No \\
& & \\
\hline Abla & & $\mathrm{X}$ \\
Fahad & $\mathrm{X}$ & \\
Luci & $\mathrm{X}$ & \\
Pablo & $\mathrm{X}$ & \\
Renato & $\mathrm{X}$ & \\
Ricardo & $\mathrm{X}$ & \\
Takeshi & $\mathrm{X}$ & \\
Victor & $\mathrm{X}$ & \\
\hline
\end{tabular}


Five students in the intermediate group expressed interest in knowing how their NNS teachers have learned the language. For example, Ana said that she wanted to know "The way they [NNS teachers] learn English. I want to know how they get it." In the same way, Carlos stated that he wanted to be as proficient as his NNS teachers. He pointed out: "I think it's... I want to express like they; learn the language, understand the language as good as they do."

Three subjects disagreed with their classmates. Furthermore, Fatimah expressed her disappointment about having had NNS teachers in her native Saudi Arabia. Fatimah stated: “No, I don't think so. In Saudi Arabia I had teacher Egyptians. And, you know, when I came here I hear the word different from I learned.” In addition, when I asked Fatimah to tell me about the best English teacher she had ever had, she burst out: "No, I don't have anyone... because all these I had before in Saudi Arabia are not good. Here is better than in Saudi Arabia."

The number of students who see their NNS instructors as inspiring individuals is greater in the advanced group. Seven out of the eight subjects in the advanced group look up to their NNS instructors. Some students commented on the hard work that nonative speakers have to endure in order to become teachers. Renato said: "Yes, he [the NNS] learned about the language, and I think that's a good thing - that you're not selfish [self-centered] to know just your language. He had to study a lot because to be a teacher in a nonnative language they study hard. They have to study a lot. That's it." Likewise, Ricardo stated, “...they [NNSs] are here working, studying hard. It's a model to follow, the persistence." Takeshi put the nonnative speaker teachers in his shoes. He believed NNS teachers and he shared the same learning experiences. He said that he thought of 
NNS teachers as models "Because... native teacher knows English by nature. So they didn’t study English. But nonnative teacher studied English; so they know how to study English, and how to learn new vocabulary. I think it's a model to follow." Similarly, Luci stated: "Yes, because [of] my experience with the nonnative teacher speakers in the USA that I had, I think they know a lot of English, and they are working every single day to improve their knowledge."

Only one student in this group said that she did not see NNS teachers as models. Abla explained: "I don't have a model in my life. So... maybe my father only. I don't think I'm going to have a teacher as a model. All the teachers, nobody, no! No, I don't think so!"

\section{Previous Experiences with NNS Teachers}

In this section, I report on comments made by the students about their previous experiences with nonnative speaker teachers of English. These comments include both negative and positive experiences. Table 6 , presented at the end of this section, summarizes the kinds of experiences the students had with their NNS teachers. All except one student reported good previous experiences, and all except two reported bad experiences. One person reported only bad experiences, and two reported only good experiences. Thirteen of the 16 , however, indicated that they had had both good and bad experiences with NNS instructors, and elaborated on their responses.

One topic that seemed to be of great concern for the students was pronunciation. Ahmed and Fatimah were dissatisfied with the pronunciation teaching they had received from NNS teachers in their native Saudi Arabia. Ahmed explained: "Sometimes the teachers nonnative from Middle East, Arabic speakers...their pronunciation is different 
because Arabic language is not the same place [he pointed to his tongue and lips] of English when they speak." Also, Fatimah argued: "In Saudi Arabia, I had teachers Egyptians. And, you know, when I came here I hear the words different from I learned." She added, "Some [NNS teachers] give you a grammar or vocabulary, but can't give you a correct pronunciation to them. So I can’t learn English.”

Similarly, four advanced students claimed to have had EFL teachers whose pronunciations were faulty. For example, Abla stated that ...[this] teacher in Kuwait, she was teaching me English, and she was mad because her accent was not clear to me. I couldn't understand from her. Her pronunciation was so bad. And, sometimes, if I wanted to argue with her about some point that I couldn't understand, or I don't agree, she wouldn't listen to me. The two participants from Brazil had similar perceptions of their teachers' pronunciation. Renato noted: "Sometimes I had a teacher in Brazil; she was from Chile, and her pronunciation wasn't good. Her entire style to teach was a problem." Ricardo's instructor, on the other hand, was a Brazilian EFL teacher who, according to him, did not have a "nice" accent. However, according to Ricardo, she was a knowledgeable teacher. He pointed out:

Once I had a teacher in Brazil and the teacher didn't have a nice accent, but just accent; but it is not related to knowledge. She knew English, I mean, the language, but just about the accent... but I mean, this is not about lack of knowledge.

Takeshi, too, was unhappy about the pronunciation of his EFL teachers. On the other hand, he was amazed by the way English is pronounced in the United States. He 
said that he had never been taught that kind of pronunciation in Japan. As noted earlier Takeshi learned to say 'alotof' as a chunk, rather than pronouncing each word separately, and attributed this heightened awareness to his study in the USA. Also, as Takeshi pointed out, in Japan

They teach you grammar, reading, discuss vocabulary - no oral communication. So we consider "/ $1 /$ " and "/ $\mathrm{r} /$ " is the same pronunciation because in Japanese it is the same. So, for example, if we want to go to 'library,' we say it we say it with Japanese pronunciation; and 'literally' is too hard to pronounce for me.

Another concern that both the intermediate and the advanced group demonstrated discontent with was some EFL teachers' nonprofessional attitudes toward teaching. Carlos stated that he had had teachers who did not care about the students. He claimed: In my country, in my school, I had a lot of bad teachers. They never speak in... they never spoke in English. They always speak in Spanish. Just go in there... stay in the class, and play stupid games. Nobody cares about that [the games]. He added: “And they put homework, stupid homework, and... I didn’t learn anything about... in that class."

Also, Nasser complained about not receiving extra help when he needed it. He said:

It was bad English [teacher] because if I had a problem, he said, "I don't have a time." He didn't learn [teach] me. He finished the class, and if I had a question, I ask he; and he say, "The class is finished, I can't help you." Gloria complained about some teachers in her high school in Venezuela. She claimed that they did not provide thorough explanations of the topics covered in class. In 
addition, according to Gloria, they assigned a lot of exercises and homework on those topics.

Abla, one of the advanced students, complained about a teacher who was not open to discussions. She remarked that the teacher, instead, used to scream and be extremely authoritative in the classroom. Abla's description of this instructor was: "She was crazy!" Another complaint that Takeshi brought up was lack of knowledge on the part of his Japanese EFL teachers. Takeshi stated:

In high school I learned from Japanese teachers. But I learned English by myself at that time. Maybe my knowledge is superior to their knowledge. Especially in grammar, they didn't know the logic how to reduce adjective clauses; they didn't know the reduction, special reduction. So, when I came here, native teacher told me how to reduce. So, in some point... Japanese teachers have lack of knowledge. Contrary to all of his peers, whose bad experiences happened in EFL contexts, Pablo claimed that the only bad experiences he had with NNS instructors took place in the United States. He illustrated his point of view with an incident from one of his classes with this instructor. Pablo explained:

For example, I saw in one opportunity, I don't know her name, but she throw the chalk to [at] the student. She did it seriously. She didn't... she couldn't catch the attention of the student. So this was her way to call the student. I don't remember her name.

Students in both groups, nevertheless, reported instances of positive experiences that they had with nonnative teachers in EFL contexts. In the intermediate group, Ahmed and Francisco stated that they had professional NNS teachers in their native 
countries-Saudi Arabia and Venezuela, respectively. In addition, three students in the advanced group mentioned their good learning experiences with NNS instructors in the EFL context. For example, Abla noted that some NNS instructors who taught her English in Kuwait were aware of the limitations their students had as nonnative speakers. Therefore, the instructors explained things to them in a simple manner. Abla said, "In my country, some nonnative speakers who taught me were better than a native speaker." Also, she explained: "They [the instructors] give... try to... they understand that you can't speak perfectly and they have the patience to... they try to give the information in a simple way." Likewise, Ricardo claimed that most of his teachers in Brazil were good. He stated: "You know, in Brazil, most of my teachers, they were good teachers." 
Table 6

Summary of Students' Previous Experiences with NNS Teachers

\begin{tabular}{lll}
\hline $\begin{array}{l}\text { Intermediate } \\
\text { students }\end{array}$ & Good & Bad \\
\hline Ahmed & $\mathrm{X}$ & $\mathrm{X}$ \\
Ana & $\mathrm{X}$ & $\mathrm{X}$ \\
Carlos & $\mathrm{X}$ & $\mathrm{X}$ \\
Fatimah & & $\mathrm{X}$ \\
Francisco & $\mathrm{X}$ & \\
Gloria & $\mathrm{X}$ & $\mathrm{X}$ \\
Marta & $\mathrm{X}$ & \\
Nasser & $\mathrm{X}$ & $\mathrm{X}$ \\
\hline \multicolumn{1}{c}{ Advanced } & & \\
$\quad$ Students & & \\
& & \\
\hline Abla & $\mathrm{X}$ & $\mathrm{X}$ \\
Fahad & $\mathrm{X}$ & $\mathrm{X}$ \\
Luci & $\mathrm{X}$ & $\mathrm{X}$ \\
Pablo & $\mathrm{X}$ & $\mathrm{X}$ \\
Renato & $\mathrm{X}$ & $\mathrm{X}$ \\
Ricardo & $\mathrm{X}$ & $\mathrm{X}$ \\
Takeshi & $\mathrm{X}$ & $\mathrm{X}$ \\
Victor & $\mathrm{X}$ & $\mathrm{X}$ \\
\hline
\end{tabular}




\section{Other Issues}

In spite of the fact that in this study the researcher was interested in finding out the students' perceptions of NNS teachers, some issues related to NS teachers emerged. These topics, which include, grammar and vocabulary knowledge, cultural awareness, nonprofessional attitude, came up when the students answered a question about teachers' knowledge. Some of the students' remarks are presented below.

Carlos, from the intermediate group, mentioned that he was disappointed about his NS teacher's lack of grammar knowledge. He recalled: “[It was] something with the grammar that I couldn't understand." He continued: “A native speaker, sometimes they don't know how to explain the grammar."

Ana, Carlos' roommate, said she expected her NS teacher to know the word 'inveigle.' She said: "Yeah, one time I asked a native teacher about one word: 'inveigle.' That's somebody push you to do something bad, negative." Ana found it unacceptable that she, an intermediate student, knew the word; whereas her teacher did not.

Lack of awareness of cultural differences caused two advanced students to be upset. Fahad commented angrily about a teacher he had in San Diego, California. Fahad's anger was the result of his teacher's jokes about his religious belief. Fahad recalled: "He offended [me]. He can't understand my religion and offended me. I hate him! I changed the class." Takeshi's complaint reflects a cultural misunderstanding as well. Takeshi explained: 
I wanted to know how American people know about Japanese culture. Some American teacher yelled 'banzai' in Japanese. I was really offended because 'banzai' means sometimes good expression, sometimes bad expression. And 'banzai... during World War II many young people rode on the plane without returning fuel; only go. So, when they leave from Japan, many people say 'banzai' to encourage him. So I remember that my grandfather died from atomic bomb. So I have a bad feeling from World War II. American people don't know other areas' culture. So sometimes I would be offended, even though they don't mean to offend. So it's very difficult. If they have no vicious, I don't care. But if they intend to offend me, I do care; and maybe I'll be mad.

In addition to the cultural issues, another student from the advanced group complained about his ESL grammar teacher. He pointed out:

I think I can see when the teacher didn't prepare the class because when you ask her questions, they take the question and respond you the next class. So I think that the teacher didn't prepare very well the class, something like that. For example: Mary. Maybe two or three times, some students ask to Mary [grammar questions], and she didn't answer that day. She answered on the next class.

Similarly, Luci commented on her missing out on something when her grammar instructor could not answer her question about the usage of '-ing' with 'would rather' and 'prefer.' She explained: 
Sometimes [they] don't answer my question at the time. But then they say: "OK, I'm going to find [out], I'm going to check it, look it up and then I'm going to solve your question." But then at that time you are losing something.

In summary, the data reflected that the students' responses could be grouped into five different categories, all of which will be discussed in detail in chapter 5 . 


\section{Chapter 5}

\section{Discussion}

This chapter contains the discussion of the findings within each of the five categories presented in chapter 4: students' perceptions of NNS teachers' characteristics; ESL students' preferences; NNS teacher credibility; NNS teachers as models; and previous experiences with NNS teachers. The findings reported here seem to indicate that most of the subjects have a positive perception of NNS teachers. I was able to come to this conclusion based on the comments made by the participants in the interviews and in the questionnaires, and from my 21 hours of observations in the IEP classes. In the following sections, a more detailed basis for this conclusion is presented.

\section{Students' Perceptions of Nonnative Speaker Teachers' Characteristics}

The characteristics of NNS instructors most often mentioned by the students were physical appearance, accent, and non-English first names. It has been reported in the literature that ESL students seem to perceive white, European-looking teachers of ESL as native speakers of English (Amin, 1999; Shaw, 2001). In accordance with Amin's and Shaw's research, in this study, too, the subjects believed NS instructors were white, blue/green-eyed individuals. Conversely, NNS were not thought of as sharing these physical features. The student's comments support the findings reported by the previous researchers. As Nasser said, "Some teacher I know they look from somewhere [else]." His peer, Victor, stated he was able to tell an instructor was a NNS of English “...only for the appearance because [of] the color of the hair, the eyes - physical appearance..." Interestingly, Deniz's looks wrongly lead her students to believe she is a native speaker of English. Deniz is a Turkish woman in her mid-twenties with green-eyes, very fair skin, 
and light brown hair. Her words corroborate the students' comments. She said that she usually lets her students know that she is a NNS in the first week of class. She mentioned:

They all know I'm from Turkey. However, if a student joins my class late, and if they do not know that I am Turkish, they continue to believe that I am American.

It is funny since I have a thick accent, but, I guess, they are misled because of my appearance.

Once again, this shows that the students perceive NNS teachers as individuals who do not have the appearance traditionally attributed to NS teachers of English. While these perceptions might grow out of individual preconceived notions, they remain the perceptions of the participants. At the same time, the issue of prejudice and how it might influence the perceptions of the students is beyond the scope of this study.

On the other hand, one participant in the advanced group was aware of the fact that not all NSs have the white European looks. Luci wisely said that although she knew that individuals who are non-white are seen as NNS speakers, this is not always the case. Luci explained: "However, in USA, you know there are a lot of cultures and stuff, and they [NNS instructors] can be a second generation of people that came here."

In addition to looks, the accent is decisive for the recognition of NNS instructors. Nevertheless, with one exception, the students in the intermediate group were not critical of a nonnative accent in ESL contexts. They only said they could tell it was different from a native speaker's. No positive or negative comments were made.

It seems that ESL students have another tool for identifying nonnative speakers: the instructors' names. If a teacher has a name that does not sound English to the student, he assumes the teacher is not a native speaker. As mentioned before, Carlos explained, 
"If their name is weird, I realize - 'Oh, this guy is not from here. They don't have that kind of name here." Contrary to the intermediate group, the instructor's name was not pointed out by the advanced group as an indicator of nationality or language background.

All in all, the most important key element that the students mentioned as being characteristic to nonnative speaker teachers was their accent. According to the students, it deviates from the correct accent - the one belonging to native speakers only. Apparently, the students were not aware of the fact that being exposed to nonnative forms of accents could provide them with good aural practice; which is part of the information students receive every semester during the orientation week in the intensive English program where they were enrolled.

\section{ESL Students' Preferences}

Another dimension of the students' perceptions was their preferences for either NS or NNS instructors. Although Amin (1999) found that ESL students prefer NS teachers; that did not seem to be the case in this study. Instead of a hard-and-fast choice for NS teachers only, what I found in this study was quite different. That is, the students reported preference for both NS teachers and NNS teachers. Moreover, it was clear from the students' comments that they tended to prefer native speaker teachers for American culture, writing, and communication skills classes.

The large majority of the students said they would prefer a NS teacher for American culture, communication skills and pronunciation classes. Apparently, their choices emerged from their concern about culture knowledge and the "right" accent. This supports Strevens' (1980) assertion that the increase in [language] diversity, which can be extended into the realm of different accents, generates anxieties related to 
acceptability “... especially for non-native speakers of the language...” (p. 61). Thus, it holds true for the students in my study; for they seemed to be searching for a native form of accent - in this case, the American one. This might be the "...inordinate amount of emphasis placed on the right accent..." that Walelign (1986, p. 40) talks about.

When talking about their preferences, the students made various comments that clearly allowed me to perceive how mixed their choices were. For example, Carlos pointed out that NNS teachers were better, but the NS teachers knew more slang. Also, Renato asserted that

A good English teacher, he has a good pronunciation. He knows all the grammar rules. And he knows the street speak. He just don't know the academic one. He know the colloquial speech. He knows all about the English language. One aspect of Renato's notion of a good English teacher does not rule out NNSs as potential candidates for good ESL teachers more than it does NSs. Renato's last requirement that the teacher know "... all about the English language” seems to be unattainable for both NSs and NNSs.

Although the students perceived NNSs as better vocabulary teachers, Renato's observation, nevertheless, put the nonnative speaker teacher at a disadvantage. Renato said that a good English teacher knows the "street speak" and the "colloquial speech." Reves and Medgyes (1994) cleverly state that "Teaching EFL/ESL necessitates both oral and written proficiency, the appropriate use of English in various social situations and at a level far above the learners' proficiency level" (p. 304). In addition, the authors say that "Their [NNSs'] deficit is greater if they work in less privileged teaching situations, cut off from NESTs [NS teachers] or any native speakers" (p. 364). If the authors' statements 
are true, and if we assume that the majority of NNS teachers have not lived in an Englishspeaking country for extended periods of time, it seems to be virtually impossible for them to know the colloquialism and slang employed in everyday conversations - which is precisely what the student mentioned.

Contrary to the mixed opinions of her peers, Fatimah was $100 \%$ against being taught by nonnative speaker teachers. It appears that Fatimah's unfortunate experiences with NNS teachers in Saudi Arabia shaped her aversion to NNS teachers as a whole. Much of her negative attitude about having NNS instructors was related to their accents. Some of the comments Fatimah made on her questionnaire were:

Native speakers help me to listen and pronounce the words correctly more than nonnative... With nativ[e] teacher I can learn and practise the language more than nonnative... She [a NNS] cannot give the information directly and sometime she confuse me...In Saudi Arabia I had teachers Egyptians. And, you know, when I came here I hear the words different from I learned.

Although Fatimah held a B.A. in English from a Saudi university, she was a student in the intermediate group in the IEP. Apparently, this participant was absolutely displeased with her situation; which was understandable, given her previous negative experience. When she moved here, she intended to enroll in the Linguistics Graduate Program at WVU. Instead, because of an insufficient TOEFL score, she decided to take classes in the Intensive English Program to improve her English skills.

During the in-class observations, I could notice that Fatimah's attitude toward the instructor did not seem to be the same as that of her classmates. Oftentimes, Fatimah 
appeared to be annoyed in class. Conversely, the rapport between the instructor and the other students in the group could not have been better.

The notion that the ideal teacher of English is a NS, known as the native speaker fallacy (Canagarajah, 1999), holds true in Fatimah's case. Moreover, it discredits the competence of nonnative speakers. Also, as Illés (1991) points out, this “...view carries the unmistakable implication that native English speakers are blessed with the innate capacity to teach" (p. 87).

Whereas NS teachers were chosen for American culture, communication skills, pronunciation, and writing classes, the NNS teachers were the choice for grammar, vocabulary, and TOEFL preparation classes. The interviews and questionnaires provided considerable information on how the students felt about having NNS instructors for these classes. For example, as reported in chapter 4, Luci stated that NNS teachers had better knowledge of grammar rules. Similarly, Renato mentioned that grammar rules were more readily accessible to NNS teachers because of their need to learn the language themselves. In addition, Takeshi noted that NNS teachers were better at teaching vocabulary because of their experience as learners. Therefore, they knew more synonyms and better techniques for teaching vocabulary. These perceptions of the students support Milambiling's (1999) assessment of NNS instructors. Milambiling (1999) asserts that NNS teachers may share their learners' "thought worlds" because of their own experiences as learners. Luci's, Renato's, and Takeshi's observations about the NNSs' competence seem to further support Canagarajah's (1999) argument that the proficiency NNSs have in more than one language helps them develop “...deep metalinguistic 
knowledge and complex language awareness" (p. 80). Hence the capability NNSs have to teach, which was perceived by the subjects.

As noted earlier, Reves and Medgyes (1994) posited “...that the higher the nonNESTs' [NNS teachers'] proficiency level in English, the less self-conscious, hesitant and insecure they will be" (p. 364). In addition, the authors state that the NNSs who had more frequent contact with native speakers or had spent longer periods of time in English-speaking countries, besides having acquired a wide range of vocabulary, were more at ease with the language with respect to fluency and language authenticity. Reves and Medgyes' findings are corroborated by Abla's and Renato's comments. The two students said that the NNS teachers they had met in the United States were good teachers. Furthermore, Abla commented that having a NS or a NNS as teacher “.... is the same. I mean, here in the United States, for me, it's the same because both of them I think are good. I learn from them. I can understand from them. So I think it's the same.”

Given the fact that the students based their preferences on the attributes they perceived in both NSs and NNSs teachers, Kamhi-Stein's (2000) proposal for mutual help between both categories seems beneficial to these two types of teachers. As the author puts it, both categories “...have much to learn from each other" (p. 13). NNS Teacher Credibility

This category derived from the participants' responses to a question on whether or not they tested NNS teachers. The intermediate students' responses were divided. That is, four participants said they did test their NNS teacher, and four said they did not. The answers given by the students indicate that they trusted their NNS instructors. 
Although half of the participants said they had their means of testing NNS teachers, they also admitted to testing NS teachers as well. Therefore, I concluded that the degree of credibility devoted to NNS teachers was the same as the credibility NS teachers received.

Surprisingly, of the eight subjects in the advanced group, all but one student stated they did not test NNS teachers. Just the same, the one subject who admitted having asked his nonnative teachers questions to test them said he only did that outside the United States. Victor said: "In Colombia; but not here." At first, the fact that the advanced students tend not to test NNSs, or NSs for that matter, seemed unexpected. I believed that students whose language knowledge was higher would be more critical, and consequently, more skeptical of their instructors' competence. The data do not support that expectation.

The findings in this study show that there were two different degrees of credibility NNS instructors received from the intermediate and the advanced students. That is, teachers in charge of intermediate groups were subject to more skepticism on the part of their students than those in charge of more advanced students. This could be attributed to two factors. First, the students might be aware of the fact that in the intensive English program where the study was conducted, more experienced teachers tend to be assigned more advanced levels to teach. Second, it could be attributed to the unique make-up of the classes, or possibly the group atmosphere and attitude. 


\section{NNS Teachers as Models}

Medgyes (1992) argues that only NNS teachers can serve as models of successful language learners. Likewise, based on her experience as a professional in a TESOL teacher training program in the United States, Milambiling (1999) states that

...many of the non-native speakers who are learning to be teachers will actually be more successful at teaching English than would native speakers in the same teaching situations. Among the reasons for this are that the non-native speakers have had the experience of learning English themselves and also because they understand and may inhabit 'thought worlds' that are similar to those of their students (p. 4).

One of the findings in this study gives some support to the opinions of the two authors above. That is, the majority of the students interviewed - fourteen of the sixteen participants - saw NNS teachers as good examples of successful language learners. The various comments the subjects made about NNS teachers conveyed this idea. Their statements were related to positive attributes, such as competence, hard work, and achievement. For instance, Ana said: "Yes. The way that they learn English. I want to know how they get it. They...I don't know. That's why I like Deniz [her grammar instructor], she know the formulas for everything. And she say, 'everything is in the book." Similarly, Carlos stated that he wanted to be as proficient as his NNS teachers: “...I think it's...I want to express like they; learn the language, understand the language as good as they do." Renato praised the hard work of NNS teachers. He said: "He had to study a lot because to be a teacher in a nonnative language they study hard. They have to study a lot. That's it. He's like uh... a hard worker." Ricardo, similarly, said that NNS 
teachers studied hard and had persistence. Also, Takeshi felt that “...nonnative teacher studied English; so they know how to study English, and how to learn new vocabulary. I think it's a model to follow."

Albeit Abla said many positive things about NNS speaker teachers, she adamantly stated that she did not have any models in her life. As noted earlier, she was insistent on this point: "I don't have a model in my life. So...maybe my father only. I don't think I'm going to have a teacher as a model. All the teachers, nobody, no. No, I don't think so."

Taking into consideration all the positive statements the subjects made about how much their NNS teachers had attained with hard work and linguistic knowledge, it would appear that the participants did see their NNS instructors as models to follow.

\section{Previous Experiences with NNS Teachers}

When talking about their previous experiences with NNS teachers of English, the students mentioned both positive and negative aspects. Of the sixteen participants in the study, thirteen reported having had both positive and negative experiences. Two subjects stated that they had had only positive experiences with NNSs; and one student stated that she had experienced only negative teaching from NNSs.

One salient pattern in the previous experiences the participants had with NNS teachers was their dissatisfaction with their teachers' accents, all of them in EFL contexts. For instance, Ahmed explained: "Sometimes the teachers nonnative from Middle East, Arabic speakers... their pronunciation is different because Arabic language is not the same place [he pointed to his tongue and lips] of English when they speak." Also, Takeshi complained about his former EFL teachers in Japan, whose pronunciation was different from what he learned later in the United States. One of Takeshi's 
complaints was his inability to distinguish the "/ $1 /$ " and "/ $/$ /" sounds in English because he had not been properly taught. Furthermore, Renato complained about his Chilean EFL teacher in Brazil, reporting that “...her pronunciation wasn't good.”

Although the illustrations above are related to pronunciation, there were other concerns mentioned by the students. Some subjects also demonstrated discontent with poor grammatical knowledge and nonprofessional attitudes on the part of some of their previous NNS teachers.

On the other hand, one of the positive comments made by Abla confirms Tang's (1997) findings of a survey she conducted in Hong Kong. Abla stated that “... They [NNSs] understand that you can't speak perfectly and they have the patience to...they try to give the information in a simple way." Likewise, when Tang (1997) asked questions about advantages and disadvantages for learners to have NS and NNS teachers, she found that “....another advantage for NNESLTs [NNS teachers] reported by some respondents is that their previous L2 learning experience offers them a privileged understanding of the problems and weaknesses of their students" (p. 578). Furthermore, Abla added that NNSs remembered when they were students themselves; hence their sympathy toward the learners.

\section{Other Issues}

The issues related to NS teachers mentioned by the participants in this study indicate that NSs, too, have their share of problems in the classroom. Moreover, it appears that, with the exception of pronunciation, these instructors and their counterparts, the NNSs, share the same problems. Given the nature of the positive and the negative 
issues pointed out by the participants in the study, it appears that mutual help between NS instructors and NNS instructors is advisable.

In summary, when the data were analyzed, five categories emerged: students' perceptions of NNS teachers' characteristics; ESL students' preferences; NNS teacher credibility; NNS teachers as models; and previous experiences with NNS teachers. The discussion of these five categories shows that both the positive and the negative comments made by the students have implications for the classroom. This will be addressed in greater detail in the next chapter. 


\section{Chapter 6}

Conclusion

\section{Review of the Study and Findings}

My purpose in conducting this study was to investigate how ESL students perceived their nonnative speaker teachers of English. As mentioned earlier, in order to find out how students see their NNS teachers, researchers typically have drawn on the NNS teachers themselves. Departing from this point, and from Milambiling's (1999) suggestion that there be more research on NNS teachers, I decided to carry out this investigative research. However, in my study, I used a different approach. Instead of asking the instructors how they thought their students saw them, I asked the students directly. The research question I proposed to find an answer to was: How do ESL students perceive their nonnative teachers?

When I analyzed the data generated by the students' response to a questionnaire, in-class observations, and interviews with the students, I found five categories into which the data could be classified. They were: students' perceptions of nonnative speaker teachers' characteristics; ESL students' preferences; NNS teacher credibility; NNS teachers as models; and previous experiences with NNS teachers. These categories are revisited briefly in this section along with some implications for the classroom.

The analysis of the characteristics that ESL students perceive in NNS teachers indicates that the students relied mostly on the teachers' accents and physical appearance as means to identify them as NNSs. Only one student out of the sixteen participants seemed to be aware of the diverse ethnicity in the United States. The rest of the students 
believed native speakers were white, blue/green-eyed individuals with white European looks. Although the students had this stereotypical notion of NNS teachers, they did not associate the teachers' looks with incapacity to teach proper English; which was one of Amin's (1997) findings.

The findings in this study demonstrate that both NSs and NNSs can be perceived as successful teachers by the students. Moreover, my findings indicate that ESL students do have their preferences as to what kind of teacher, native or nonnative, they would rather have. These preferences are based on the types of classes they are taught. On one hand, the majority of the students expressed that they would prefer to have a NS teacher to teach classes such as oral communication, writing, and American culture. On the other hand, NNS teachers seemed to be the students' preference to teach grammar, TOEFL preparation, and vocabulary classes.

As previously mentioned, intermediate students tend to test their instructors more than advanced students do. One reason that might account for this finding is the tendency in the intensive English program in which the study was conducted for NNS teachers who are more proficient and more experienced to be assigned to teach groups at more advanced levels. Perhaps the ESL learners in this study were aware of this practice; hence the advanced students' more positive attitude toward, and acceptance of, their NNS instructors. Also, the intermediate students who said that they were skeptical of their instructors' knowledge of vocabulary referred to both NNS and NS instructors. Consequently, both NNS teachers and NS teachers were tested by the students. However, despite the intermediate students' testing of their instructors, it seems that not only do 
language learners trust their NNS teachers' linguistic knowledge, but they look up to them also.

The students' accounts of their previous experiences indicate that they had both positive and negative learning experiences with NNS teachers. On the negative side, the students' main concerns were related to their NNS teachers' accents. For the most part, the students were displeased with the poor pronunciation of some of their NNS speakers in the EFL context. According to some of the participants in this study, they realized that they had not learned good English pronunciation in their home countries upon coming to the United States. On the other hand, the majority of the students praised their ESL and EFL NNS teachers' good command of English grammar as well as their patience.

\section{Implications for the ESL Classroom}

The hiring practices in the program where this study was carried out differ from those described in chapter 2. As reported in the review of the literature section, both implicit and explicit practice seemed to indicate that a priority is given to NS teachers in the hiring process (Walelign, 1986; Braine, 1999; Kamhi-Stein, 2000). However, the results of this study showed that these students do not always prefer NS teachers. Instead the participants believed NSs are better suited to teach pronunciation and oral skills because they have the "right accent." However, their preference for vocabulary, TOEFL preparation, and grammar classes seemed to be for NNSs. The participants in this study suggested that NNS teachers are sensitive and sympathetic toward the students' difficulties in their process of learning grammar and vocabulary. The students attributed this fact to the instructors' experiences as language learners themselves. Based on these findings, it is appropriate to suggest that, when feasible, administrators take this into 
account when making instructional assignments, in order to better accommodate students' preferences. That is, students should be given the opportunity to have a NNS teacher for grammar, and a NS for oral communication classes. Grammar and communication skills were the two classes for which the students in this study were more assertive about their preferences.

In addition to being trusted due to their attainments as second/foreign language learners themselves, NNS teachers were seen as models of successful language learners by most students in this study. Some students expressed that they wanted to know more about how their instructors had learned English. Medgyes' (1992) argument that only NNS teachers can serve as models of successful language learners was supported by the findings in this study. In view of this, I find it important that NNS teachers who have mastered English emphasize to their students that the students, too, can become proficient users of English if they work consistently and persistently toward their goals.

Both the negative and the positive experiences reported by the students have implications for the classroom. The quality of their instructors' pronunciation seemed to be their main concern, especially in the EFL context, because the students felt that it had an impact on their own learning. In view of this, it seems appropriate to suggest that NNS teachers devote some time to work toward improving their own pronunciation. By saying this, I am not suggesting that NNS teachers try to get rid of their accents, which would be virtually impossible. What is of great importance, though, is that teachers, native or nonnative, are the models learners have. Hence the NNS teachers' need to have oral language skills that feature clear pronunciation of words, with correct use of stress, and good intonation in order to transmit meaning most effectively. This being achieved, NNS 
teachers will be able to better teach pronunciation to their students, who might stop searching for the right accent. Consequently, NNS teachers will have their accents added to the list of assets learners perceive in them.

\section{Limitations of the Study}

There are several limitations in this study that should be noted. First, since this is a qualitative study, the researcher relied on the statements made by the participants. That is, when responding to questions on a questionnaire and in an interview, participants may not always be truthful, or give complete answers. As Marshall and Rossman (1999) put it, "In using questionnaires, researchers rely totally on the honesty and accuracy of participants' responses" (p. 129). Moreover, since both the questionnaire and the interview were in English, participants with limited oral English proficiency skills may not have been able to articulate their answers in full depth, as in Carlos' use of the word "weird" when commenting on the names of NNS instructors. As a consequence, an incomplete interpretation of their viewpoint may have been rendered. Also, the use of yes/no questions both in the interview and on the questionnaire might have posed limitations to the answers given by some of the participants. In addition, the researcher's own perceptions of the participants' attitudes and behaviors may have colored his interpretation. In view of this, the researcher acknowledges that it is possible that the findings in this study have some degree of subjectivity. Furthermore, the fact that the researcher in this study is a NNS himself might have influenced the students' answers. Had the students been interviewed by a NS, their answers might have been different. Finally, since this is a qualitative study, the students' perceptions of nonnative ESL teachers reported here cannot be generalized. 


\section{Recommendations for Further Research}

Since many of the participants in this study focused on the pronunciation of NNS teachers in EFL contexts, more research is needed to investigate the students' perceptions of NNS teachers in EFL contexts. One question that emerged during the interview process and the class observations was: How do EFL students who have never been in the ESL environment perceive their nonnative speaker teachers? Also, it would be interesting to conduct interviews with students about their preferences for teachers at the beginning of the semester and at the end to see if experience mitigates prejudice. In addition, it is recommended that the present study be replicated in other IEPs where students are not informed of the benefits of having NNSs as instructors.

\section{Conclusion}

The purpose of this study was to find out more about ESL students' perceptions of nonnative speaker teachers of English. The data for the study were gathered by means of a student questionnaire, one-to-one interviews with the students, and class observations. The data analysis indicated the emergence of five categories related to the students' perceptions. These categories consisted of NNS teachers' characteristics, students' preferences, NNS teacher credibility, models for learners, and students' previous experiences with NNS teachers. Overall, the analysis of the data collected in this study showed that the ESL students' perceptions of their NNS teachers are positive. 
Works cited

Amin, N. (1997). Race and the identity of the non-native ESL teacher. TESOL Quartely, 31, 580-583.

Amin, N. (1999). Minority women teachers of ESL: Negotiating white English. In G. Braine (Ed.), Non-native educators in English language teaching (pp. 93-104). Mahwah, NJ: Earlbaum.

Amin, N. (2001). Marginalization of non-white immigrant women ESL teachers in Canada. TESOL Matters, 11.2, 9.

Árva, V, \& Medgyes, P. (2000). Native and non-native teachers in the classroom. System, 28, 355-372.

Astor, A. (2000). A qualified nonnative English-speaking teacher is second to none in the field: The perspective of a Russian tenured (assistant) professor in New York since 1993. TESOL Matters, 10.2, 19.

Berry, R. (1990). The role of language improvement in in-service teacher training programmes: Killing two birds with one stone. System, 18, 97-105.

Birdsong, D. (1992). Ultimate attainment in second language acquisition. Language, 68, 706-755.

Braine, G. (Ed.). (1999). Non-native educators in English language teaching. Mahwah, NJ: Earlbaum.

Brutt-Griffler, J., \& Samimy, K.K.(1999). Revisiting the colonial in the postcolonial: Critical praxis for nonnative-English-speaking teachers in a TESOL program. TESOL Quarterly, 33, 413-431. 
Canagarajah, A. (1999). Interrogating the "native speaker fallacy": Non-linguistic roots, non-pedagogical results. In G. Braine (Ed.), Non-native educators in English language teaching (pp. 77-92). Mahwah, NJ: Lawrence Earlbaum Associates.

Chalupa, C., \& Lair, Anne (2001). Meeting the needs of international TAs in the foreign language classroom: A model for extended training. In B. Rifkin (Ed.), AAUSC Mentoring foreign language teaching assistants, lecturers, adjunct faculty (pp. 119-142). Boston: Heinle \& Heinle.

Cook, V. (1999). Going beyond the native speaker in language teaching. TESOL Quarterly, 33, 185-209.

Coppieters, R. (1987). Competence differences between native and near-native speakers. Language, 63, 545-573.

Crystal, D. (1987). The Cambridge Encyclopedia of Language. Cambridge: Cambridge University Press.

Crystal, D. (2001). The future of Englishes. In A. Burns \& C. Coffin (Eds.), Analysing English in a global context (pp. 54-55). London: Routledge.

Cullen, R. (1994). Incorporating a language improvement component in teacher training programmes. ELT Journal, 48, 162-172.

Davies, A. (1991). The native speaker in applied linguistics. Edinburgh, Scotland: Edinburgh University Press.

Doff, A. (1987). Training materials as an instrument of methodological change. In R. Bowers (Ed.), An integrated programme for ELT teacher training. Basingstoke: Macmillan for Modern English Publications.

Edge, J. (1988). Natives, speakers, and models. JALT Journal, 9, 153-157. 
Forhan, L. (1992). Nonnative speakers of English and hiring practices. TESOL Matters, 2, 22-23.

Graddol, D. (2001). English in the future. In A. Burns \& C. Coffin (Eds.), Analysing English in a global context (pp. 26-37). London: Routledge.

Greis, N. (1984). Toward a better preparation of the non-native ESOL teacher. On TESOL `84, 317-324.

Harmer, J. (1991). The practice of English language teaching. New York: Longman. Howatt, A. (1984). A history of English language teaching. Oxford: Oxford University Press.

Illés, E. (1991). Correspondence. ELT Journal, 45, 87.

Kachru, B. (1982). Introduction: The other side of English. In B.B. Kachru (Ed.), The other tongue: English across cultures (pp. 1-12). Chicago: University of Illinois Press.

Kachru, B., \& Nelson, C.L. (1996). World Englishes. In S.L. Mckay \& N.H. Hornberger (Eds.), Sociolinguistics and language teaching (pp. 71-102). Cambridge, England: Cambridge University Press.

Kamhi-Stein, L. (2000). Adapting U.S.-based TESOL education to meet the needs of nonnative English speakers. TESOL Journal, 9, 10-11.

Kramsch, C. (1997). The privilege of the nonnative speaker. PMLA, ll2, 359-369.

Lee, I. (2000). Can a Nonnative English Speaker Be a Good English Teacher? TESOL Matters, 10.1, 19.

Leung, C., Harris, R., \& Rampton, B. (1997). The idealised native speaker, reified ethnicities, and classroom realities. TESOL Quarterly, 31, 543-559. 
Liu, D. (1998). Ethnocentrism in TESOL: Teacher education and the neglected needs of international TESOL students. ELT Journal, 52, 3-10.

Liu, J. (1999). Nonnative-English-speaking professionals in TESOL. TESOL Quarterly, 33, 85-102.

Marshall, C., \& Rossman, G. (1999). Designing qualitative research (3 ${ }^{\text {rd }}$ ed.). Thousand Oaks, CA: SAGE Publications.

McNeil, A. (1994). Some characteristics of native and non-native speaker teachers of English. Paper presented at the Annual International Language in Education Conference. Hong Kong.

Medgyes, P. (1992). Native or non-native: Who's worth more? ELT Journal, 46, $340-349$.

Medgyes, P. (1994). The non-native teacher. London: Macmillan.

Milambiling, J. (1999). Native and non-native speakers: The view from teacher education. Paper presented at Annual Meeting of the Midwest Modern Languages Association. IOWA

Milambiling, J. (2000). Comments on Vivian Cook's "going beyond the native speaker in language teaching." How nonnative speakers as teachers fit into the equation. TESOL Quarterly, 34, 324-328.

Norton, B. (1997). Language, identity, and the ownership of English. TESOL Quarterly, $31,409-429$.

Paikeday, T. (1985). The native speaker is dead! Toronto: Paikeday Publishing Inc. 
Palfreyman, D. (1993). How I got it in my head: Conceptual models of language and learning in native and non-native trainee EFL teachers. Language Awareness, 2,209223.

Pennycook, A. (2001). English in the world/the world in English. In A. Burns \& C. Coffin (Eds.), Analysing English in a global context (pp. 78-89). London: Routledge.

Phillipson, R. (1992). ELT: The native speaker's burden? ELT Journal, 46, 12-17.

Polio, C., \& Wilson-Duffy, C. (1998). Teaching ESL in an unfamiliar context: International students in a North American MA TESOL practicum. TESOL Journal, 7, (4), 24-29.

Rampton, M.B.H. (1990). Displacing the 'native speaker': Expertise, affiliation, and inheritance. ELT Journal, 44, 97-101.

Reves, T., \& Medgyes, P. (1994). The non-native English speaking EFL/ESL teacher's self-image: An international survey. System, 22, 353-367.

Richards, J.C., Platt, J., \& Platt, H. (1992). Dictionary of language teaching and applied linguistics (2 ${ }^{\text {nd }}$ ed.). Essex, England: Longman.

Richards, J. C., Rodgers, T. (1986). Approaches and methods in language teaching. Cambridge: Cambridge University Press.

Rickford, J. (1996). Regional and social variation. In S. L. Mckay \& N. H. Hornberger (Eds.), Sociolinguistics and language teaching (pp. 151-194). Cambridge: Cambridge University Press.

Rose, K. (1997). Pragmatics in teacher education for non-native speaking teachers: A consciousness-raising approach. Language, Culture and Curriculum, 10, 125-138. 
Samimy, K.K., \& Brutt-Griffler, J. (1999). To be a native or non-native speaker:

Perceptions of "non-native" students in a graduate TESOL program. In G. Braine (Ed.), Non-native educators in English language teaching (pp. 127-144). Mahwah, NJ: Earlbaum.

Shaw, D. G. (2001). Cross-cultural gender dynamics in classroom interaction: The adult ESOL classroom. Dissertation Abstracts International, Section A, 62 (05): p. 1691.

Strevens, P. (1977). New orientations in the teaching of English. Oxford: Oxford University Press.

Strevens, P. (1980). Teaching English as an international language: From practice to principle. Oxford: Pergamon Press.

Tang, C. (1997). The identity of the nonnative ESL teacher. On the power and status of nonnative ESL teachers. TESOL Quarterly, 31, 577-580.

Thomas, J. (1999). Voices from the periphery: Non-native teachers and issues of credibility. In G. Braine (Ed.), Non-native educators in English language teaching (pp. 5-13). Mahwah, NJ: Earlbaum.

Walelign, A. (1986). Nonnative speakers need not apply. English Teaching Forum, 24, $40-41$.

White, L., \& Genesee, F. (1996). How native is near-native? The issue of ultimate attainment in adult second language acquisition. Second Language Research, 12, 233 265.

Widdowson, H.G. (1992). ELT and EL teachers: Matters arising. ELT Journal, 46, 333339.

Widdowson, H.G. (1994). The ownership of English. TESOL Quarterly, 28, 377-389. 


\section{Appendix A}

Table 1

Countries Where English Has Official Status

\begin{tabular}{|l|l|l|}
\hline Antigua and Barbuda & Irish Republic & Seychelles \\
Australia & Jamaica & Sierra Leone \\
Bahamas & Kenya & Singapore \\
Barbados & Lesotho & South Africa \\
Belize & Liberia & Suriname \\
Bermuda & Malawi & Swaziland \\
Botswana & Malta & Tanzania \\
Brunei & Mauritius & Trinidad and Tobago \\
Cameroon & New Zealand & Uganda \\
Canada & Nigeria & United Kingdom \\
Dominica & Pakistan & United States of America \\
Fiji & Papua New Guinea & Zambia \\
Gambia & Philippines & Zimbabwe \\
Ghana & Puerto Rico & \\
Grenada & St Christopher and Nevis & \\
Guyana & St Lucia & \\
India & St Vincent and the Grenadines & \\
\hline
\end{tabular}

Source: Adapted from Crystal (1987), p. 357 


\section{Appendix B}

A TESOL Statement on Nonnative Speakers of English and Hiring Practices Whereas TESOL is an international association concerned with the teaching of English to speakers of other languages and composed of professionals who are both native and nonnative speakers of English, and

Whereas employment decisions in this profession which are based solely upon the criterion that an individual is or is not a native speaker of English discriminate against well-qualified individuals, especially when they are made in the absence of any defensible criteria, and Whereas such decisions, not based on sound criteria, must therefore be in contradiction to sound linguistic research and pedagogical practice, Therefore, be it resolved that the Executive Board and the Officers of TESOL shall make every effort to expunge from all publications of TESOL and its affiliated bodies all language supporting such discrimination, and

Therefore be it further resolved that the Executive Board and the Officers of TESOL shall make every effort to prevent such discrimination in the employment support structures operated by TESOL and its own practices, and Therefore be it further resolved that the Executive Board of TESOL shall instruct the Committee on Professional Standards (and such other TESOL bodies as the Board sees fit to involve) to work towards the creation and publication of minimal language proficiency standards that may be applied equally to all ESOL teachers without reference to the nativeness of their English. 
This resolution is moved by the Sociopolitical Concerns Committee, having been drafted by the Employment Issues Subcommittee and endorsed by the committee of the whole.

October 1991

Source: TESOL Matters, August/September 1992. 
Appendix C

\section{STUDENT CONSENT and INFORMATION FORM \\ Students' perceptions of nonnative ESL teachers}

Introduction. I, , have been invited to participate in this research study which has been explained to me by Etelvo Ramos Filho. This research is being conducted to fulfill the requirements for a master's thesis on the ESL students' perceptions of nonnative instructors in the Department of Foreign Languages at West Virginia University.

Purposes of the Study. The purpose of this study is to learn more about students' feelings and attitudes toward being taught by nonnative teachers.

Description of Procedures. This study involves a survey questionnaire to be completed by the student participants, audio-taped student interviews, and class observation. Approximately fourteen students are expected to participate in this study. The researcher will observe a minimum of 20 classes and take notes on the behavior of the students participants. The interviews will last about 20 to 30 minutes each, and they will be taperecorded. The tapes containing the interviews will be kept in office of the researcher Etelvo Ramos Filho during the duration of the study. When the research is completed, the tapes will be destroyed and disposed of properly so that these data are not available to anyone. I have been told that I may see the questionnaire and the interview questions before signing this consent, and that I do not have to answer all the questions if I decide to participate in this study.

Risks and Discomforts. There are no known or expected risks from participating in this study.

Alternative. I understand that I do not have to participate in this study.

Benefits. I understand that this study is not expected to be of direct benefit to me, but the knowledge gained may be of benefit to others.

Contact Persons. For more information about this research, I can contact Etelvo Ramos Filho at (304) 598-3835, or his supervisor, Dr. Frank Medley, Jr. at (304) 293-5121, ext. 5504. For information regarding my rights as a research subject, I may contact the Executive Secretary of the Institutional Review Board at 304/293-7073.

Version date 3-12-02

$\overline{\text { initials date }}$


Students' perceptions of nonnative ESL teachers

Confidentiality. I understand that any information about me obtained as a result of my participation in this research will be kept as confidential as legally as possible. I understand also that my research records, just like hospital records, may be subpoenaed by court order or may be inspected by federal regulatory authorities. In any publications that result from this research, neither my name nor any information from which I might be identified will be published without my consent.

Voluntary Participation. Participation in this study is voluntary. I understand that I am free to withdraw my consent to participate in this study at any time. Refusal to participate or withdrawal will involve no penalty or loss of benefits and will not affect my grades or class standing. I have been given the opportunity to ask questions about the research, and I have received answers concerning areas I did not understand.

Upon signing this form I will receive a copy.

I willingly consent to participate in this research.

Signature of Subject

Signature of Investigator
Date

Date
Time

Time

Version date 3-12-02

$\overline{\text { initial date }}$




\section{Appendix D}

Questionnaire

1. What is your name? Please print.

2. Gender: ( ) male ( ) female

3. Age: ( ) under $18 \quad$ ( ) 18-24 $\quad$ ( ) 25-32 $\quad$ ( ) older

4. What country are you from?

5. What is the language you speak with your parents?

6. How many years have you been studying English?

7. How many hours per week?

8. Why are you learning English? Please check all of these that apply in order of importance. $1=$ most important to $5=$ least important
( ) job
( ) leisure
( ) interest in culture
( ) graduate studies
( ) other:

9. What other languages can you speak?

10. In what kinds of school did you take English?

11. How many different teachers of English have you had?

( ) one ( ) two ( ) three ( ) four ( ) five ( ) more than five What were their nationalities?

12. What are your self-study methods? Please check all of these you do regularly.
( ) listen to radio
( ) watch TV programs in English
( ) read English publications ( ) other: 
13. What is a native speaker?

14. Have you been taught by ( ) native speakers ( ) nonnative speakers?

15. I prefer being taught by:

( ) native speakers ( ) nonnative speakers ( ) it doesn't matter

Please justify:

16. Do you think nonnative teachers understand your questions more easily?

( ) yes ( ) no ( ) the same as native teachers

17. Can you tell a teacher is not a native speaker before he/she tells you his/her name?

( ) yes ( ) no If yes, how?

18. Do you see a nonnative teacher as a model to follow? ( ) yes ( ) no

19. Does being taught by someone who learned the language the same way you are learning it help you? ( ) yes ( ) no ( ) not important

20. Are there any classes you would rather be taught by a nonnative teacher?

( ) yes ( ) no If yes, which ones?
( ) American Culture
( ) TOEFL
( ) Communication Skills ( ) Grammar
( ) Writing/ Study Skills ( ) Reading/Vocabulary

Please explain: 
21. What was your last TOEFL score?

22. Have you ever been disappointed by a teacher's lack of knowledge?

( ) yes ( ) no If yes, was he/she

( ) a native speaker?

( ) a nonnative speaker?

( ) some were natives; some were nonnatives

23. What was something this teacher didn't know that bothered you? 


\section{Appendix E \\ INTERVIEW QUESTIONS}

1. What is your name?

2. What is your highest academic level achieved?

3. Are you going to enter college in the USA?

4. Have you been taught by nonnatives here in the USA or in your country?

5. Do you see a nonnative teacher as a model to follow? How?

6. Are there any classes you would prefer to be taught by a nonnative teacher? Please explain.

7. Have you ever been disappointed by a teacher's lack of knowledge?

Was he/she a native or a nonnative teacher?

8. Can you tell a teacher is not a native speaker before he/she tells you his/her name? Please explain.

9. Do you prefer being taught by native speakers or nonnative speakers? Why?

10. Describe a good English teacher.

11. How can you tell if the teaching of the nonnative teachers of English is good or not?

12. Are nonnative teachers more patient, less patient, or the same as native speaker teachers? Please explain.

13. Describe a bad English teacher.

14. Tell me about the best English teacher you ever had.

15. Tell me about the worst English teacher you ever had.

16. Do you ever ask nonnative teachers questions to test them?

17. Have you ever had good learning experiences with nonnative teachers? 
18. Have you ever had bad learning experiences with nonnative teachers?

19. Have you ever had good learning experiences with native teachers?

20. Have you ever had bad learning experiences with native teachers? 
Appendix F

TEACHER INTERVIEW

1. Where are you from?

2. Please describe in what situations you have taught English.

3. How long have you been teaching ESL?

4. What is your highest academic level achieved?

5. How long have you lived here (USA)?

6. Do you tell your students you are a nonnative speaker? If so, when? Why?

7. If you don't tell them, in what other ways might they find out?

8. Do you think students treat you differently because you are a nonnative speaker? If so, explain how you know that they treat you differently.

9. How do you respond when students ask you difficult questions about the language and culture?

10. Can you give examples of times when students seem to be challenging your knowledge of English? 